\title{
SDU\%
}

\section{Real wages, labour conditions and the standard of living in Denmark: 1500-1900}

by

\author{
Cristina Victoria Radu
}

Discussion Papers on Business and Economics

No. $2 / 2019$

FURTHER INFORMATION Department of Business and Economics Faculty of Business and Social Sciences University of Southern Denmark Campusvej 55, DK-5230 Odense M 


\title{
Real wages, labour conditions and the standard of living in Denmark: 1500-1900
}

\author{
Cristina Victoria Radu* \\ University of Southern Denmark
}

\begin{abstract}
It is well established that Denmark is one of the richest economies in the world nowadays with high living standards and wages. But what about earlier times? This paper makes three contributions: firstly, it creates and describes a new and rich data set on historical wage developments in Denmark, based on data gathered by the Danish Price History Project for the period 1660-1800; secondly, it tests the traditional view of Denmark being very poor during that period by offering insight into eighteenth century Danish living standards; and thirdly, it tests whether the country followed the traditional story of the Little Divergence by constructing a long run real wage series for 1500-1900. Comparing real wages across Europe, I find incomes in the countryside actually converged in the sixteenth century. In this context, Denmark moved from being poor, to an average income level, becoming rich only in the nineteenth century. An analysis of the eighteenth century shows that the value of the skill premium was higher than that of leading countries in Europe, but the gender wage gap tended to close towards the end. Married women in skilled occupations earned more than unmarried ones, but no difference was seen for unskilled occupations.
\end{abstract}

Keywords: Little Divergence, Denmark, consumer price Index, real wages, skill premium, gender gap, casual and full time workers, married/unmarried women, urban/rural workers, living standards

JEL Classification: J3, J4, J8, N33, N93

${ }^{1}$ I am grateful to Peter Sandholt Jensen and Paul Richard Sharp for very useful help and suggestions. I would also like to thank Christian Skovsgaard, Kathryn Gary, Battista Severgnini, Susanne Krogh Jensen, Sheilagh Ogilvie, Joyce Burnette, Philipp Ager, Lars Lønstrup, Peter Juul Egedes $\emptyset$, Ingrid Henriksen, Jacob Weisdorf as well as the participants at the Interdisciplinary Workshop in Economic History at the University of Southern Denmark (2017), Odense and World Economic History Congress (2018), Boston for useful comments and discussions. All errors are my own. The research in this paper was supported by a grant from the Danish Agency for Science, Technology and Innovation.

*Cristina Victoria Radu: Postdoctoral researcher, Department of Business and Economics, University of Southern Denmark, Campusvej 55, DK-5230 Odense, Denmark. Email address: cvr@sam.sdu.dk 


\section{Introduction}

A growing body of literature focuses on constructing and analysing wage series for different countries for the distant past. Such endeavours have been revitalised with Allen's contribution in which he builds real wages for unskilled and skilled workers for up to 20 European cities, by making use of archival data from the fourteenth century to the First World War. Allen (2001) found a divergence pattern in Europe between 1500 and 1800, as wages fell in most parts of Europe, but were maintained in the North Sea region, namely in England and the Low Countries - the so-called Little Divergence. The latter was and still is an ongoing debate, as new data on historical GDP, real wages and other indicators ${ }^{2}$ for different countries are being used to test its traditional story (see e.g., Allen 2001, de Pleijt and van Zanden 2016, Khaustova and Sharp 2015, Humphries and Weisdorf 2017, Gary 2018, Stephenson 2018).

However, one case where detailed data so far have been missing from the international evidence is Denmark, for which only aggregate wage data have been constructed relying on secondary sources (Khaustova and Sharp 2015, Abildgren 2017). Moreover, we have limited knowledge of the Danish economic development before 1800, as GDP per capita data are missing ${ }^{3}$, and real wage data that have long coverage are available only for parts of the country. Another part of the motivation for turning our focus to Denmark is its undisputed status as one of the richest economies in the world today with high living standards and high wages. Thus, in this context it is interesting to investigate where this case belongs in the Little Divergence debate, and to establish when Denmark had her economic take-off by using a long real wage series.

Thus, this paper creates a new comprehensive data set on wages for the eighteenth century rural Denmark based on wage data collected by the Danish Price History Project, a project which was initiated at the University of Copenhagen in 1939 and terminated in 2004. The data were collected on the basis of accounts and material from the Danish government, the royal court and its property, the army, firms, churches, and from local and private archives. Although these data are referenced and briefly summarised in the two volumes "History of Prices and Wages in Denmark 1660-1800" (Friis and Glamann 1958 and Andersen and Pedersen 2004), they have not otherwise been exploited to construct real wage data. It contains information on wages for a variety of occupations, for men, women and children at 17 different manors and two households, resulting in a total of 21,557 observations. To my knowledge, no such data exist for any other country for such an early period. Concerning prices, which are used for producing real wage series, there are more than 30,000 observations, and I make use of information on free market operations for several types of commodities traded. More precisely, for each manor and household, it is possible to identify the quality of

${ }^{2}$ Indicators, such as urbanization, book consumption, literacy rates and human capital have been used to show that indeed, there was economic progress in England and the Low Countries as opposed to the situation in the countries from Eastern and Southern Europe (de Pleijt and van Zanden 2016); Dall Schmidt et al. (2018) show that Denmark was experiencing increased urban populations from at least the 1840s.

${ }^{3}$ Hansen (1984) provides estimates of national income, but only starts in 1818 , and the data have several drawbacks. However, a group of researchers at the University of Southern Denmark is currently working on a project involving the development of GDP numbers before 1800, with the help of a grant received from the Danish Research Council. 
the good, the amount traded and the price of the transaction, allowing for a regional comparison in terms of real wages, which previous studies exploiting wage data for Denmark did not undertake. Moreover, the present wage data are collected for the countryside area, as opposed to most other datasets in the literature, which are available only at the city level. In addition, secondary sources enable the construction of a long run wage series for Denmark in the period 1500-1900, allowing for international comparisons and addressing the Little Divergence debate.

The findings are briefly summarized here: putting together an international comparison of real wages from the countryside areas shines a new light on the little divergence debate, showing that although England was richer than the rest of Europe, the gap actually closed in the sixteenth century and remained smaller in the seventeenth and eighteenth century, only to diverge again in the nineteenth century. In this context, Denmark starts out a poor country, but catches up to continental Europe countries in the seventeenth century, becoming a rich country in the nineteenth century. The value of the skill premium calculated using the wages of unskilled labourers and craftsmen was more unstable and higher than that of the leading countries in Europe. This can often be associated with less developed institutions that have a role in barriers to social mobility, like serfdom. Craftsmen, however, were earning on average $80 \%$ more, which is better than values seen in other parts of Europe. By looking at the real wage from a regional perspective, we can observe a trend of convergence in income at the regional level. Furthermore, women received lower wages than men for doing jobs that required the same skill level, but the wage gap tended to close towards the end of the eighteenth century. The detailed data allow a comparison between the wages of married and unmarried women, which reveals that women in occupations requiring skills earned more when they were married, but day labourers showed no difference in wages. Because marital status is correlated with age, the result suggests that women doing skilled occupations, who had more experience, got better wages, and thus women having skilled occupations had an incentive to stay longer on the labour market.

This paper proceeds as follows: sections two, three and four present the literature, data, explain the data sources, and offer a historical context by outlining the most important historical events taking place at the time, section five describes the method used in the analysis, section six reports the results, and finally, section seven presents the conclusions.

\section{Literature and contribution}

Existing Danish evidence regarding the wage development dates back to Scharling (1869) and FalbeHansen (1869) who provided data for the fifteenth and sixteenth centuries for workers receiving salaries and those receiving payment in kind in Copenhagen and in the countryside. Their data are composed of averages across a number of years. For the period taken into consideration in the present study, Thestrup (1987) presents annual time series of daily wage data for workers in Copenhagen receiving monetized payments, as well as wages for payments in kind for shorter periods of time. Christensen (1985) has detailed (although not annual) information on many types of agricultural wages (men/women, summer/harvest/winter, etc.) from 
1829, whereas for the later years Ølgaard (1976) provides a wealth of data both from the cities and the countryside. In the twentieth century, regular surveys of wages were performed by Statistics Denmark. Recent studies, such as Khaustova and Sharp (2015), construct wage series for men and women in urban and rural occupations and find that Denmark was poor during the eighteenth century, but caught up with the leading European economies over the next century, so that "already by the 1870 s laborers in Copenhagen enjoyed some of the highest living standards in Europe". They suggest that the high wages are one possible cause of the mechanization, which later led to high productivity in agriculture. Abildgren (2017) also makes use of the scattered data available in previous studies, mostly for Copenhagen, to analyze the development of wages in Denmark, and estimates that the average growth rate of wages was between $-0.08 \%$ and $0.00 \%$ for the period from 1500 to 1820 .

This paper also links to the international literature on the importance of historical wages in Scandinavia. Jorberg (1972) provides the foundation for the work on historical Swedish prices, and analyses real wage series for unskilled agricultural workers in Sweden from 1731. Söderberg (2010) enriches this analysis by documenting the data for Stockholm back to the sixteenth century. He concludes that the real wage trends during the preindustrial period display a Malthusian pattern, followed by a takeoff in both population and real wages in 1870. Gary (2018) develops a new set of wage series for unskilled and skilled workers, including women in Scania, in the early modern period, concluding that stagnant and falling real wages combined with a high and unstable skill premium led this region to fall behind more developed areas of North-Western Europe during the Little Divergence. The data available in the Wedervang Archive, allowed Grytten (2009) to construct and examine wage developments and the standard of living for workers in Norway from the early eighteenth century until 1940, within eight industries.

Finally, this study speaks to a broader debate in the international literature, namely the Little Divergence according to which England and the Low Countries had a stable income and growth ahead of other European countries before the industrial period. As mentioned previously, there have been lots of studies which focus on either testing this story or on explaining its causes by using either real wages or GDP data (e.g., Allen 2001, Gary 2018, de Pleijt and Van Zanden 2016).

\section{Historical context and short data description}

This section presents part of the data available from the Danish Price History Project together with a brief overview of the historical and economic background for the Kingdom of Denmark in the Early Modern Period with a focus on the eighteenth century. It should be mentioned here that the Kingdom of Denmark did not include Norway and the Duchies of Schleswig ${ }^{4}$ and Holstein, the latter forming a union with an independent administration.

\footnotetext{
${ }^{4}$ Northern Schleswig only joined modern day Denmark after First World War.
} 
One of the background factors which influenced the economy at this time was the accelerating population growth seen during the seventeenth and eighteenth centuries (Lampe and Sharp 2018). Around 1650 Denmark's population was around 550,000. This number increased to 715,000 in 1735 and 815,000 in 1774, reaching 925,000 in 1800 (Johansen 2002, Kjærgaard 1994). Figure 1 shows the location of the manors and estates covered by the Price History Project together with population density in 1769 at the county level across the three regions of Denmark, namely on Zealand, the region located in the East; on Funen, the island in the middle; and in Jutland, the peninsula in the West. Most of the manors are located on Zealand, the region that includes Copenhagen, but the data contain observations over the whole period for all three regions. The maps of the population density at the county level for the years 1787 and 1801 are shown in figure $1 \mathrm{~A}$ in the appendix.

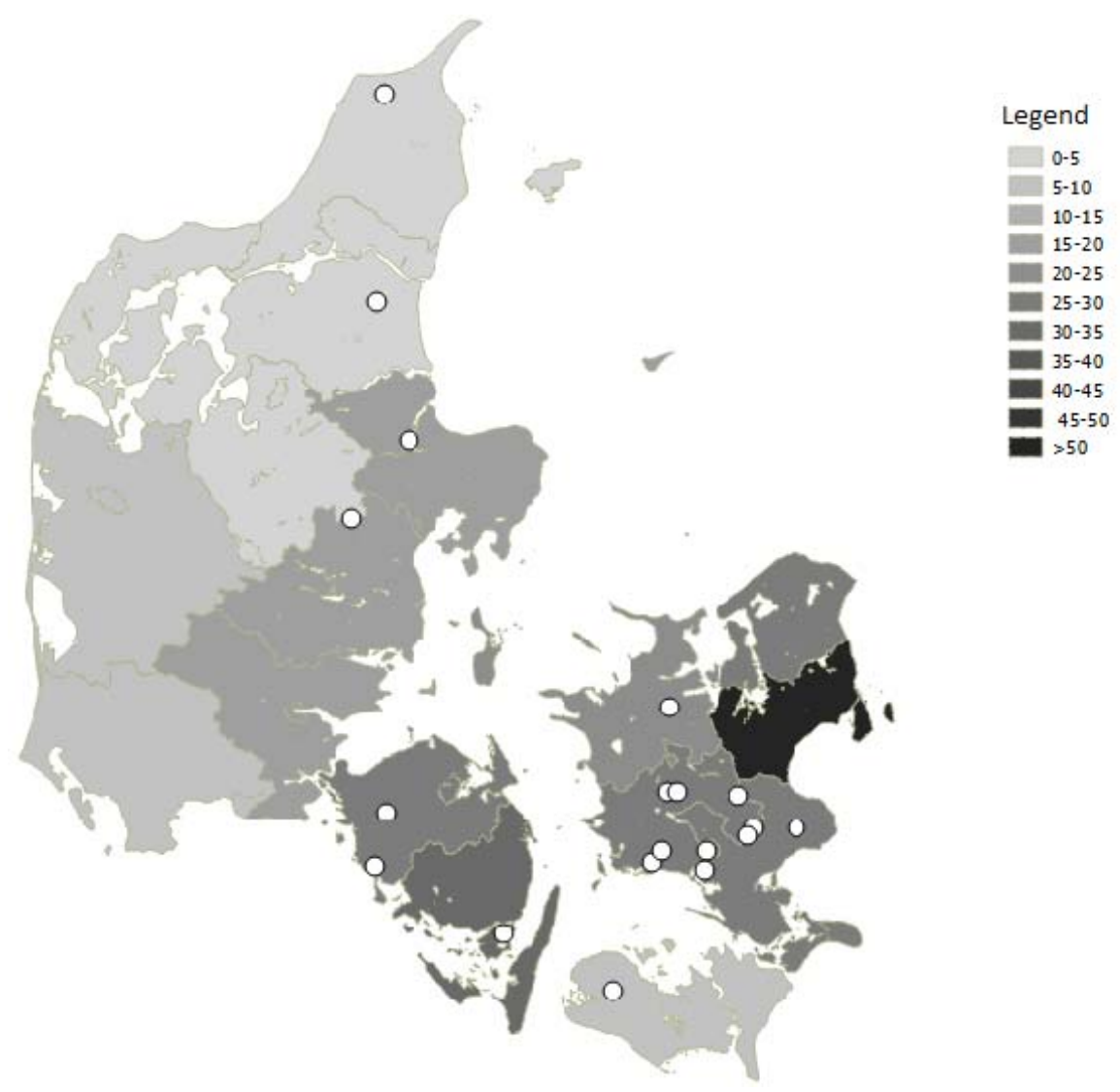

Figure 1. Population density in the Kingdom of Denmark at the county level in 1769 and the location of the manors

Note: The location of the manors and estates is represented by the white dots. The areas that are darker represent a larger population density, while the lighter ones represent a smaller density. The population density is calculated as the population in a county divided by the area of that county. Source: the population data at the country level come from the censuses available from Statistics Denmark; author's calculations in GIS software 
The data included in the Price History Project were chosen from the manors with a great level of preservation and accessibility 5 . However, it can be observed that the distribution of the manors is relatively proportional with the population distribution, with more manors available for the areas in which the population density was larger. Thus, it can be argued that there is good coverage of the whole country.

The rest of the wage data for the period 1500-1660 and for 1670-1700 are taken from books written by Scharling (1869) and Falbe-Hansen (1869). During this period, around $80-85 \%$ of the population lived from subsistence agriculture in the countryside, exporting mainly oxen and grain (Henriksen 2006). Around the year 1500, the Danish population began to slowly increase and recover after the negative effects brought on by the Black Death. The data for this century are thin, but nevertheless offer the big picture of the standard of living.

During most of the seventeenth century, Denmark had been at war with Sweden. A manor that is worth mentioning here to give a glimpse of how the occupations look like, is the Herlufsholm manor located on Zealand. One difference from the rest of the manors is that the wages cover the period 1661-1669, and the coin used for the salaries at the time was the courant-daler, which was $0.71 \%$ of the rigsdaler, the coin used for the other manors. Another difference is that it functioned as a Latin school for the children of the upper classes. It should also be noted that day wages were paid in a denomination of the rigsdaler, the skilling (sk.) which was worth $1 / 96$ of a rigsdaler (Andersen and Pedersen 2004). The school master was the best paid employee with a salary of 9,600 sk. per year, while at the bottom of the scale, teachers supervising the students' homework received only 1,296 sk. per year. The school also had a chapel minded by a sexton receiving 340 sk. per year and ran its own postal service with a postman earning 872 sk. per year. Another fact is that the school had its own brewery manned by a brewer getting 960 sk. per year and some helpers. The accounts also include the salaries of other staff responsible for the good functioning of the school like clerks, cooks, servants and gardeners. For low skilled workers we only find records for a cowman, a shepherd and fishermen. For this particular manor, the highest paid woman was the washerwoman (960 sk. and 2,496 sk. subsistence allowance). The dairy maid and a girl in charge of the storeroom received the same payment - that is, 768 sk. annually. The maid was the worst paid occupation, with 552 sk. plus 3 courant-daler for shoes in 1661.

At the beginning of the eighteenth century agriculture provided most of the state income; thus, taxes in agriculture had doubled from 1663 to 1720 . Many manors were forced to cut down forests and expand production in order to remain solvent. This required more labour, for which the manors had to compete with the military. A household from our data called Gisselfeld located on Zealand had accounts for this early period (1706-1740), and although not being very detailed, they include large number of salaries for different types of servants, such as doorkeeper, coachman and domestic servant. They received between 960 and 2,304 sk.

${ }^{5}$ Susanne Krogh Jensen at the University of Copenhagen, who was part of the team of student helpers on the Price History Project from around the year 1998, kindly offered this valuable explanation. 
per year together with food allowances varying from 4,992 to 6,656 sk. per year. The accounts also include a number of day labourers whose main tasks were related to the maintenance of the household, like working in the gardens or park, receiving 16 sk. per day. A slightly higher wage (18-20 sk.) was received for harder work, such as cutting wood, digging trenches or loading and unloading goods. More skilled workers, for example the ones cutting bushes, received 32 sk. per day.

Denmark's last major war with Sweden during this period was the Great Northern War, which lasted from 1700 to 1721 . During this time, the problems for the agricultural sector continued: while demand increased in both Denmark and Norway, increased production meant that grain prices stayed the same or even decreased. Besides the low prices, farmers had to contend with an ecological crisis because the cutting down of forests helped to form and grow sand dunes, so that by $1750,5 \%$ of the arable land in Jutland was no longer cultivated because of sand dunes (Kjærgaard 1994). The second largest estate in Jutland was Lindenborg (with records for the period 1714-1799). It was bought by a merchant who undertook a large number of repairs and modernized the estate by employing many tradesmen. A gradual shift from cattle to dairy farming led to the employment of women dairy assistants. Many records of day labourers working on the farms and in the tile works can also be found. Another estate on Jutland which has records for this period, Støvringgaard (1734-1800), constituted the economic foundation of a convent for noble women. I also mention the Frijsenborg estate (1777-1800) here, the largest in Denmark, having many farms and manors and thus many buildings which needed a large number of full time employees, like master builders, joiners, smiths, but also some who were paid by the day, like bricklayers, carpenters and stonemasons. Agricultural workers were few due to the fact that agriculture was leased out, but in return, rare professions, such as surgeon, doctor and nurse could be found. A doctor's salary increased from 19,200 sk. to 38,000 sk. from 1777 to 1790 plus the grain allowance, whereas a field surgeon received only 9,600 sk. as of 1784 . The nurse was a woman who received the same amount as the washerwoman, namely 768 sk.

In the middle of the century, deforestation also caused problems with the water level, leading to more frequent floods and transforming many previous dry areas into marshes because there was no forest to absorb the excess water (Kjærgaard 1994). Increased cultivation also led to a depletion of the nitrogen in the soil and to lower fertility. The problems for the agricultural sector continued in the 1740s, when the cattle plague struck Denmark. More than half of the country's cattle population died from the plague. Gradually, the situation of the Danish agricultural sector began to improve after that. Land was recovered by building ditches and dikes to control the water level. As this is an operation that requires much labour, many accounts of tasks like these can be seen in the records.

Because of the heavy precipitations and low evaporation, soil acidification was another problem faced by agriculture. By the 1750s the accounts from the manors of Bregentved on Zealand and Tåsinge and Frederiksgave on Funen show numerous purchases of clover seed. In contrast to the owner of Tåsinge on Funen, who avoided investments and reduced the wages of day labourers, Frederiksgave manor located on the same island, (1773-1800), pursued its modernization through constructing new buildings and improving agricultural techniques. That is also why the workers paid by the day were mainly of bricklayers, carpenters, 
builders, and their helpers as well as painters, joiners, and thatchers. As for women, the wage of a housemaid increased substantially over the period, and also included an allowance for sugar and tea, whereas the housekeeper saw only a modest increase.

Towards the end of the century we reach the so-called "Flourissante" period, in which Denmark saw strong economic development, As the country managed to stay neutral in the many conflicts that affected Europe. This period also saw the introduction of the ideas of Enlightenment, and one of the main concerns of the reformists was the conditions of the peasants. King Frederik IV abolished serfdom, gradually transforming the peasants into landowners, from 1784 to 1815 (Lampe and Sharp 2018). The medieval open field system was also abolished at the time. The economic crisis occurred when Denmark took the wrong side in the Napoleonic wars, Copenhagen was bombed by the British in 1807 and the state went bankrupt in 1813 (having lost Norway in 1811). Therefore, during this harsh 20 year period, only very few wage data exist. Detailed wage data description and data sources after 1800 can be found in Khaustova and Sharp (2015).

\section{Descriptive statistics}

The first step in preparing the database for a thorough analysis was to organise it by coding the occupational titles and tasks according to the "Historical International Standard of Classification of Occupations" (HISCO) (Van Leeuwen et al 2002) and "Historical international social class scheme" (HISCLASS) (van Leeuwen and Maas 2011). Additionally, the data were checked for outliers. For example, in some cases the wages of craftsmen are very high because they include the wages of helpers. However, not knowing exactly how many helpers these persons had and how the wage was divided between the master and his helpers meant that these observations had to be discarded. Another example is the case of teachers, who, in many cases, only received part of their salary from the manor. This meant that many teachers figured with salaries at the same level as unskilled labourers, and thus these observations also had to be ignored.

Using the system described above, the data can be classified into more than 80 occupations. HISCO codes could not be assigned for seven of the occupations/tasks, and these amounts refer to, for example money for donations, school allowances, pensioners or amounts inherited. Table $1 \mathrm{~A}$ in the appendix shows the HISCO occupations distributed according to the HISCLASS scheme. If such a classification system had not been used, simply dividing the data into skilled and unskilled labour would be difficult. The reason is that each occupation requires a certain set of skills and education to complete the tasks. The housekeeper and the teacher provide an illustrative example. Both occupations can be considered suitable for the skilled category, but the skills needed for the jobs are different. Further, the number of observations for all workers (men, women and children) distributed according to HISCLASS into unskilled, lower-skilled, medium-skilled and higher-skilled can be seen in figure $2 .{ }^{6}$

\footnotetext{
${ }^{6}$ See de Pleijt and Weisdorf (2017)
} 


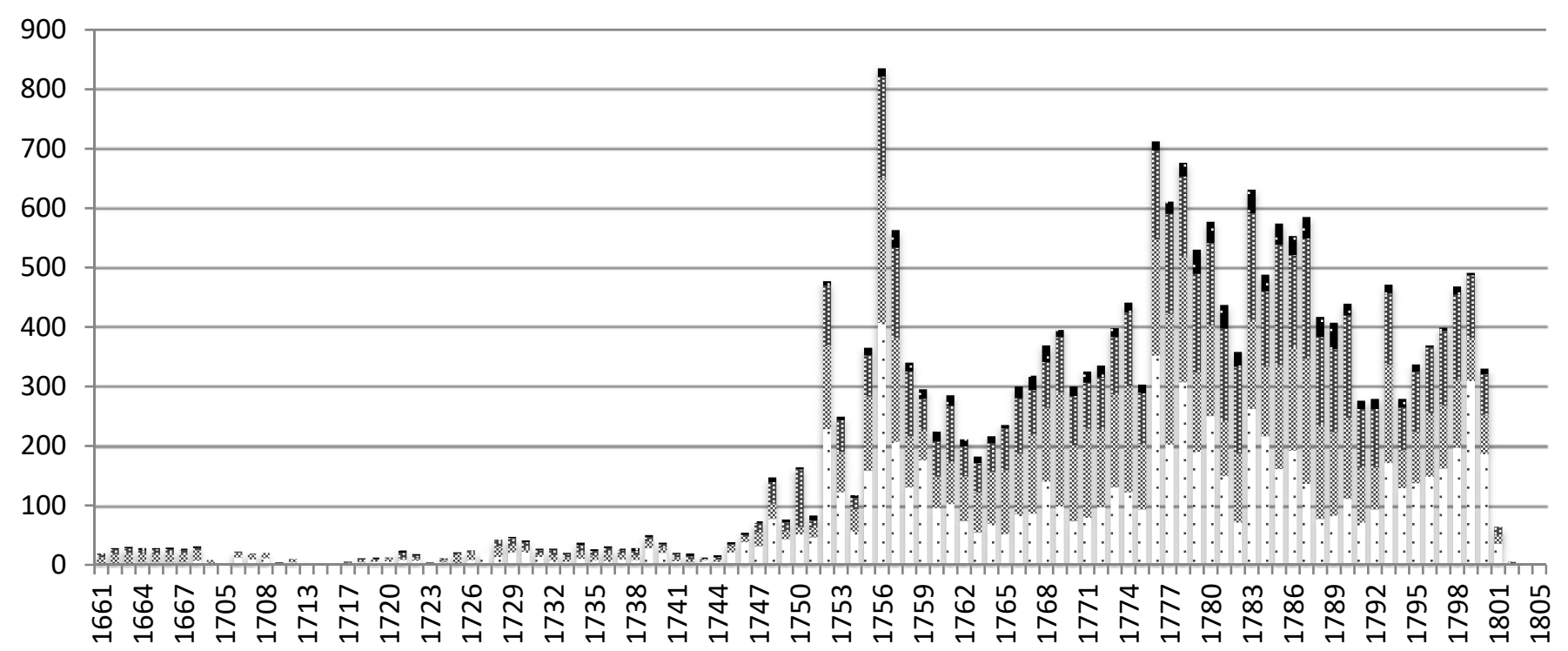

Unskilled Lower skilled $\quad$ Hedium skilled $\quad$ Higher skilled

Figure 2. Number of observations divided by HISCLASS: higher-skilled, medium-skilled, lowerskilled and unskilled workers (men, women and children). Source: author's calculations

For the period considered, the observations belonging to the unskilled and lower-skilled groups represent about $70 \%$ of total observations. ${ }^{7}$ The rest are divided between medium-skilled and higher-skilled, the latter category representing only $5 \%$ of total observations. For a more detailed classification, table 1 presents the number of observations for all occupations by region and manor as well as the percentage of each class of worker and the percentage of observations of men, women and children.

${ }^{7}$ The workers that would classify as skilled (either medium or high) would presumably be independent masters and their services could then potentially be found in the accounts as goods instead of as wages. The price-material only follows a fixed number of goods, but other goods that were bought during the period did not occur frequently enough to be included in the project. 


\begin{tabular}{|c|c|c|c|c|c|c|c|}
\hline \multirow[b]{2}{*}{ Regions and estates } & \multicolumn{4}{|c|}{$\%$} & \multicolumn{3}{|c|}{$\%$} \\
\hline & Unskilled & $\begin{array}{l}\text { Lower } \\
\text { skilled }\end{array}$ & $\begin{array}{l}\text { Medium } \\
\text { skilled }\end{array}$ & $\begin{array}{l}\text { Higher } \\
\text { skilled }\end{array}$ & Women & Men & Children \\
\hline Zealand & 37.1 & 34.0 & 24.7 & 4.2 & 3.7 & 96.3 & 2.7 \\
\hline Bregentved (1746-1800) & 38.6 & 1.8 & 59.6 & 0.0 & 0.6 & 99.4 & 0.7 \\
\hline Fuirendal (1756-1795) & 20.0 & 43.9 & 24.0 & 12.1 & 18.4 & 81.6 & 14.1 \\
\hline Gauno (1751-1800) & 22.6 & 34.1 & 31.8 & 11.6 & 2.2 & 97.8 & 3.2 \\
\hline Giesegaard (1721-1800) & 40.1 & 39.7 & 19.0 & 1.1 & 0.2 & 99.8 & 0.2 \\
\hline Gisselfeld Household (1706 1740) & 52.4 & 30.9 & 16.7 & 0.0 & 25.6 & 74.4 & 6.6 \\
\hline Herlufsholm (1661-1728) & 14.5 & 56.4 & 20.7 & 8.4 & 13.2 & 86.8 & 22.0 \\
\hline Holsteinborg (1748-1800) & 43.6 & 30.4 & 25.6 & 0.4 & 5.0 & 95.0 & 0.8 \\
\hline Juellinge (1726-1748) & 33.8 & 45.6 & 20.6 & 0.0 & 0.0 & 100.0 & 0.0 \\
\hline Løvenborg (1752-1794) & 42.7 & 34.5 & 19.4 & 3.4 & 0.7 & 99.3 & 0.6 \\
\hline Sorø Academy (1740-1800) & 9.4 & 56.2 & 33.7 & 0.6 & 0.0 & 100.0 & 0.0 \\
\hline $\begin{array}{l}\text { Funen } \\
\end{array}$ & 43.1 & 22.8 & 30.1 & 4.0 & 14.4 & 85.6 & 10.1 \\
\hline Erholm Søndergade (1723-1800) & 55.6 & 15.6 & 28.8 & 0.0 & 8.2 & 91.8 & 0.6 \\
\hline Frederiksgade $1773-1800$ & 64.8 & 18.6 & 16.4 & 0.2 & 21.0 & 79.0 & 13.6 \\
\hline Taasinge (1725-1800) & 26.7 & 27.1 & 39.1 & 7.2 & 11.5 & 88.5 & 9.9 \\
\hline Jutland & 27.2 & 31.7 & 30.9 & 10.2 & 15.8 & 84.2 & 14.9 \\
\hline Frijsenborg (1777-1800) & 23.5 & 28.7 & 36.9 & 10.9 & 9.2 & 90.8 & 11.4 \\
\hline Lindenborg (1714-1799) & 26.1 & 42.5 & 27.5 & 3.9 & 23.1 & 76.9 & 24.9 \\
\hline Odden (1703-1732) & 34.8 & 21.2 & 19.7 & 24.2 & 0.0 & 100.0 & 0.0 \\
\hline Støvringgard (and household) (1734-1800) & 34.9 & 18.3 & 27.8 & 19.0 & 15.7 & 84.3 & 4.3 \\
\hline Total & 37.1 & 30.8 & 27.1 & 5.0 & 8.4 & 91.6 & 6.5 \\
\hline
\end{tabular}

Table 1. Number of observations by region and manor, percentage of workers classified by HISCO and HISCLASS and percentage of female, child and man workers in total observations. Source: author's calculations 
The table shows that there are some imbalances in the distribution of occupations across manors which are caused by the different types of economic activities that each manor undertook. For example, Sor $\varnothing$ Akademi leased out all its land, so the number of unskilled workers is only $9 \%$. Most observations are of tradesmen doing maintenance work on the school buildings. At the opposite end of the spectrum, we find the manor of Gisselfeld, where $52 \%$ of the observations are wages of labourers doing unskilled work. The most developed manors seem to be those in the region of Jutland. In this region, the percentage of women workers is the highest (15.8\%), followed by a similar level recorded for children. An important aspect is that the medium and high-skilled jobs hold a higher proportion (41.1\%) than in the other two regions (34.1\% on Funen). Regarding the division by gender, men represented $82-96 \%$ of the workers, whereas the children were engaged in working tasks at a rate of $3-15 \%$.

The detailed data available also permit us to make observations on worker mobility. Some of the manors had data about the residence of their workers and also where they worked, if their tasks were not carried out on the estate. Figure 3 presents the data for one of the manors, where the data were more detailed, Erholm-Søndergaarde. The green dots are the workers' places of residence, while the red ones are the workplaces outside the estate.

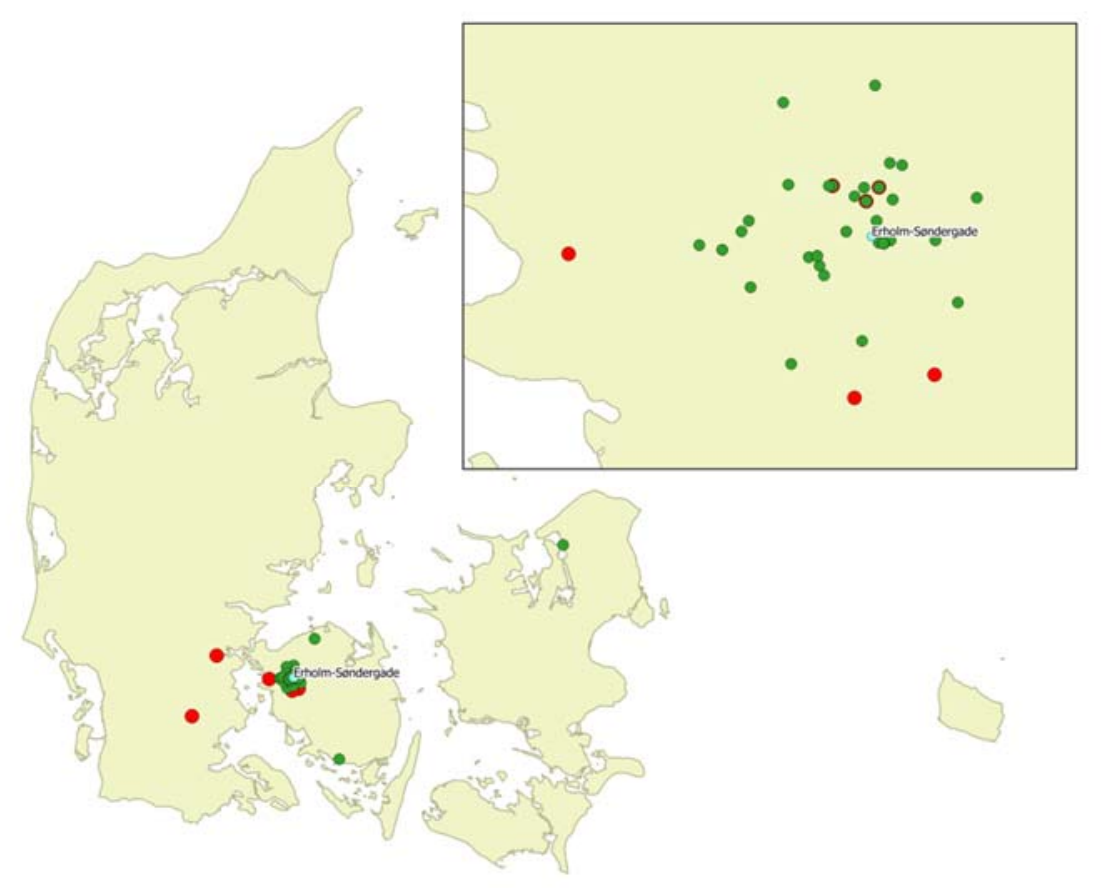

Figure 3. Worker residences and workplaces outside the manor for Erholm-Søndergaarde

Note: The square in the upper right offers a zoom into the map.

Source: author's calculations using GIS software 
It can be noted from the figure that the majority of the employees lived in the vicinity of the manor. In the case of this manor, only three craftsmen were not from the area of the estate and one travelled from the neighbouring island of Zealand. This is not surprising, because the slow means of transportation of the era meant that workers had little incentive to take a job that was not close to their home, as they would have to pay the cost of transportation and room and board close to their workplace (Collins 1999). Next, the workplaces not located on the manor can be divided into two categories. The first category covers the area close to the estate, where the owner of the manor paid a series of craftsmen and labourers to do maintenance work on important buildings in the villages, such as churches and schools. The second category of workers were workers, such as messengers and merchants who travelled further from the estate to important cities. The furthest away someone had travelled, in the case of Erholm was to the city of Haderslev which is in Southen Jutland. All in all, we can conclude that people at the time did not travel very far away from their home to their place of employment. We should note, though, that these data do not actually give any information about migration to or from a region in search of a better job.

The data set offers another valuable detail: workers' first and last names are listed for a part of the observations. This is an interesting source for revealing how long a person worked for a manor on average and how the worker's salaries changed, by tracing the names. To trace a person, we look for those workers whose name shows up at least twice in the records of a manor and who did similar jobs in all the observations. ${ }^{8}$ On average, the time between the first and the last observations for one person is a little over 10 years. Because most of the persons we could track were casual workers, they only worked on the estate for an average of 100 days in this 10-year period on the estate. ${ }^{9}$ A master mason is the person who could be tracked over the longest period of time, with 44 years between the first and last observations. As a craftsman was usually around 20 years of age when he could get the title of master, this person probably worked well into his sixties. By looking at the evolution of an individual's salaries, it can be observed that the nominal value tends to increase over time, but there is a higher rigidity in the wages of full time employees.

\section{Method}

This section describes the method used for constructing real wage series based on the detailed data from the Danish Price History Project. The first step is to aggregate the data to construct a series of nominal wages by using a slightly modified method described in Clark (2005). Next, I calculate a consumer price index based on the price observations applying the approaches from Clark (2005) and Abildgren (2010). Finally, real wages are calculated by dividing the nominal wages by the consumer price index.

\footnotetext{
${ }^{8}$ To this end I checked all the observations, and those which fulfill the conditions named above where assigned the same person id. Also, in some cases people who worked at the same manor had the same first and last name, but were doing very different jobs, and that is why I also control for occupation.

${ }^{9}$ They could also have worked at home for the rest of the time.
} 
The sample data divide the employees into two categories: full-time employees, who were paid every six months or by the year, and temporary or casual employees (day labourers or even more skilled occupations, like craftsmen), who were paid by the day. In order to compare the two categories, I started by computing the daily wage for each worker. To this end, the number of days worked in a week is necessary in order to obtain the daily wages for full-time employees (as the number of days worked per week multiplied by the number of weeks per month and the number of months worked). There are two sources from which this number can be taken. Kjærgaard (1994), in which the number of days worked per week is calculated as 5.9 days including holidays, during the eighteenth century. The second source is given in the comments that came along with the raw data. For many of the daily wage observations, these inform us about the dates between which the labourers worked, enabling the calculation of the average number of days worked per week, which it also turns out to be 5.9 days.

To obtain a representative wage value for each year, I apply an OLS regression method similar to the one in Clark (2005). He calculates annual day wage series for craftsmen, labourers and their helpers by estimating regressions which take into account all the available factors that influence wages. Having as base equation the regression in Clark (2005), I added a few modifications and get equation one:

$$
\ln \left(W_{i t}\right)=\alpha+\sum_{j=1}^{80} \beta_{j} \text { Craft }_{i}^{j}+\tau \ln \left(\text { days }_{i t}\right)+\sum_{j=1}^{106} \delta_{j} \text { year }_{t}^{j}+\text { ygender }_{i}+\sum_{k=1}^{2} \theta_{k} \text { season }_{i t}^{k}+\sum_{l=1}^{2} \mu_{l} \text { region }_{i}^{l}+\omega \text { ca }_{i}+\varepsilon_{i t}
$$

where: $\alpha=$ intercept; Craft $_{i}^{j}=$ dummy for occupation by Hisco code; $\ln \left(\right.$ days $\left._{i t}\right)=$ period of time worked; year $_{i t}^{j}=$ year dummy; gender $_{i}=$ gender dummy; season $_{i t}^{k}=$ season dummy (winter, summer, and no season); $\operatorname{region}_{i}^{l}=$ region dummy (Funen, Zealand, Jutland); $c a_{i}=$ dummy for children, $\varepsilon_{i t}=$ error term.

The difference from Clark's equation is that I add dummy variables for season, gender and child/adult, which should capture their effects on wages. Additionally, I do not use the joint wages indicator variable and the interaction term. The joint wages term is not needed because in this case there are separate observations for the craftsmen and their labourer's wages. As a robustness check, I also introduced the interactions term mentioned above, by decades in my case, but I find no statistically significant effects, likely because the data span a much shorter period than the one presented in his paper. Also, the control for the period of time worked (days worked) comes from the fact that the day rates may differ from the rates a worker received when employed full-time. I return to this in the section six. So, the representative wage comes from the prediction in equation one, and these results are also presented in session six. 
Turning the attention towards the Consumer Price Index (CPI), I deal next with the question of how to get a representative price value for each year from more than 30.000 observations on prices. Firstly, I grouped the individual prices into consumption categories in order to calculate the price levels. The categories and the weights for expenditures assigned to each of the groups can be seen in table two. Secondly, l estimate a regression which takes the form: ${ }^{10}$

$$
\ln \left(P_{i t}\right)=\mu_{i}+\sum_{j=1}^{x} \alpha_{j} c a t_{i}^{j}+\sum_{j=1}^{106} \delta_{j} \text { year }_{t}^{j}+\sum_{r=1}^{2} \beta_{r} \text { region }_{i}^{r}+\varepsilon_{i t}
$$

Where: $\mu_{i}$ is the intercept, cat represents a dummy variable for the type of goods, year $_{t}^{j}$ is a year dummy variable, region $_{i}^{r}$ is a region dummy and $\varepsilon_{i t}$ represents the error term.

There are many different ways in which the Consumer Price Index can be calculated and I chose to follow the method from Abildgren (2010) to make the results comparable to his work. ${ }^{11}$ The first step is to divide the available price series into consumption categories. Then, for each category an unweighted geometric average of the percentage change of the prices in the group is calculated. The relative change for consumption group $j$ is given by equation three:

$$
\frac{P_{t}^{j}}{P_{t-1}^{j}}==\prod_{i=1}^{n^{j}}\left(\frac{p_{t}^{i}}{p_{t-1}{ }^{i}}\right)^{\frac{1}{n^{j}}}
$$

where $P_{t}^{j}$ is the geometric average for category $j, p_{t}$ represents the price of the good and $n$ is the number of goods in the category.

Next, using these values, a Laspeyres-type index is calculated using a set of budget weights. The relative change in the $\mathrm{CPI}$ is given by:

$$
\frac{C P I_{t}}{C P I_{t-1}}=\sum_{j=1}^{M} w^{j} \cdot \frac{P_{t}^{j}}{P_{t-1}^{j}}, \text { where } \sum_{j=1}^{M} w^{j}=1
$$

where $w j$ is the budget weight of consumption group $j$.

I calculated the CPI both at the national and regional levels, and the budget weights can be seen in table 2. The budget weights, taken from Abildgren (2010), are based on private consumption expenditures from 1844, available from the Danish historical national accounts statistics. This is because 1844 is the earliest year for which a detailed commodity breakdown of private consumption is available.

\footnotetext{
${ }^{10}$ Based on Clark (2005),

${ }^{11}$ He constructed the index for Denmark from 1502 to 2007 mainly based on grain prices.
} 


\begin{tabular}{|l|l|l|}
\hline Consumption group & Commodities & Budget weight \\
\hline Bread, flour and groats & $\begin{array}{l}\text { Flour, buckwheat groats, pearl-barley, hulled rice, } \\
\text { coarse rye bread, fine rye bread, wheat bread }\end{array}$ & 0.15 \\
\hline Meat and fish & $\begin{array}{l}\text { Pigs, lambs, geese, ducks, hens, capons, chickens, } \\
\text { beef, veal, pork, herring, train oil }\end{array}$ & 0.29 \\
\hline Fat, milk, eggs and cheese & Butter, cheese, eggs, milk, cream & 0.10 \\
\hline Vegetables and fruit & Peas, apples, lemons, raisins, currants, olive oil & 0.02 \\
\hline Sugar and chocolate & Sugar, cocoa & 0.04 \\
\hline Spices, tea and coffee & $\begin{array}{l}\text { Black pepper, mace, cinnamon, cardamom, cloves, } \\
\text { ginger, coffee, tea, salt }\end{array}$ & 0.02 \\
\hline Beverages and tobacco & Beer, Danish brandy & 0.11 \\
\hline $\begin{array}{l}\text { Footwear, textiles and } \\
\text { clothing }\end{array}$ & Cloth, linen & 0.14 \\
\hline Light and fuel & & 0.08 \\
\hline Other goods & Charcoal, tallow, tallow candles, coal & 1.00 \\
\hline Total & Green soap & 0.04 \\
\hline
\end{tabular}

Table 2. Budget weights used in the construction of Laspeyres-type index

Source: author's calculations and Abildgren (2010)

For the purpose of international comparisons, I computed welfare ratios. Thus, I follow the wellknown methodology in Allen (2009), in which welfare ratios are calculated by dividing the nominal wage by the price of a basket of goods necessary for the subsistence of a family. Such prices are presented in table 3 . In other words, the welfare ratio is the average annual earnings divided by the cost of a poverty line consumption bundle for a family. A welfare ratio greater than one indicates an income above the poverty line, while a ratio less than one means that the family is in poverty. 


\begin{tabular}{|l|l|l|}
\hline & Subsistence & Respectability \\
\hline Bread & $155 \mathrm{~kg}$ & $234 \mathrm{~kg}$ \\
\hline Beans/peas & $20 \mathrm{~kg}$ & $52 \mathrm{I}$ \\
\hline Meat & $5 \mathrm{~kg}$ & $26 \mathrm{~kg}$ \\
\hline Butter & $3 \mathrm{~kg}$ & $5.2 \mathrm{~kg}$ \\
\hline Cheese & - & $5.2 \mathrm{~kg}$ \\
\hline Eggs & - & 52 \\
\hline Beer & - & $182 \mathrm{I}$ \\
\hline Soap & $1.3 \mathrm{~kg}$ & $2.6 \mathrm{~kg}$ \\
\hline Cotton & $3 \mathrm{~m}$ & $5 \mathrm{~m}$ \\
\hline Candles & $1.3 \mathrm{~kg}$ & $2.6 \mathrm{~kg}$ \\
\hline Lamp oil & $1.3 \mathrm{I}$ & $2.6 \mathrm{I}$ \\
\hline Fuel & $2 \mathrm{mbtu}$ & $5 \mathrm{mbtu}$ \\
\hline Rent & $5 \%$ of total & $5 \%$ of total \\
\hline
\end{tabular}

Table 3. The contents of Allen's subsistence and respectability consumption basket

Source: Allen (2009) 


\section{Results}

The evolution of the nominal wage series constructed for the period 1660-1800 and based solely on the data from the Danish Price History Project, is shown in figure 4.

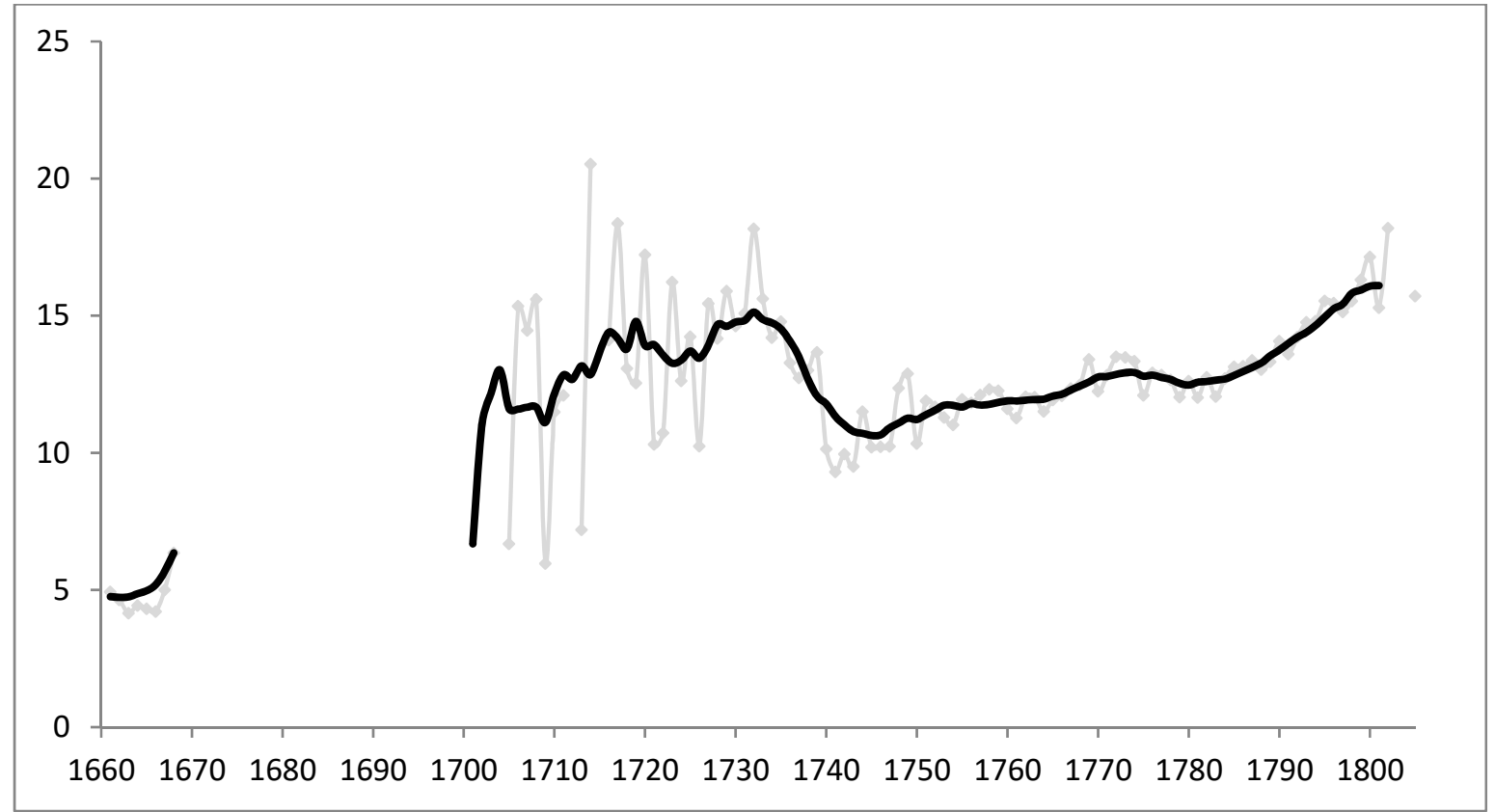

Figure 4. Nominal wages for men, women and children, 1660-1805

Note: the nominal wage series resulted from applying the OLS regression method and estimating equation 1 (see text). The black line represents the 10 year moving average. The wages are expressed in skilling/day. Source: author's calculations

A first glimpse at the figure reveals the large changes in salaries in the first part of the eighteenth century, followed by a relatively stable trend in the rest of the century. The first batch of wages, spanning from 1660 to 1668, captures a period of peace and reconstruction between the Second Northern War, which ended in 1660 and the Scanian War, which started in 1675. The nominal wages are thus relatively constant. One additional reason for the limited variation in the wage data is that only the wages of full-time workers are available for this stretch of time, and these wages tended to vary less than those of day labourers. Moving onwards, the next available series of wages starts in 1700 and ends in 1805 . The start covers the period of the Great Northern War in which Denmark actively took part in 1700 and from 1709 to 1720 . Wages in this period show a relatively high volatility, compared with the latter part of the century. After the end of the war, a period of increasing wages followed. At the time there was a migration of people from small farms to cities as some industry was starting to be built in the cities. At the beginning of the $1730 \mathrm{~s}$ an agricultural crisis took place, caused by the low demand for Danish agricultural exports and the high cost of labour. This led to the introduction of serfdom in 1733 , which is followed by a decline in the wages of unskilled labour. There is also a decrease in the wages of skilled workers probably because cash-strapped manors could not afford to hire too many skilled workers. The wages continue to decrease during the 1740 s as the manors face the ecological 
crisis and the cattle plague. As the measures to recover from the crisis kick in, the nominal wages are stable, slowly increasing during the rest of the century.

The consumer price index is calculated according to the methodology presented in the previous section, and shown in figure 5 below.

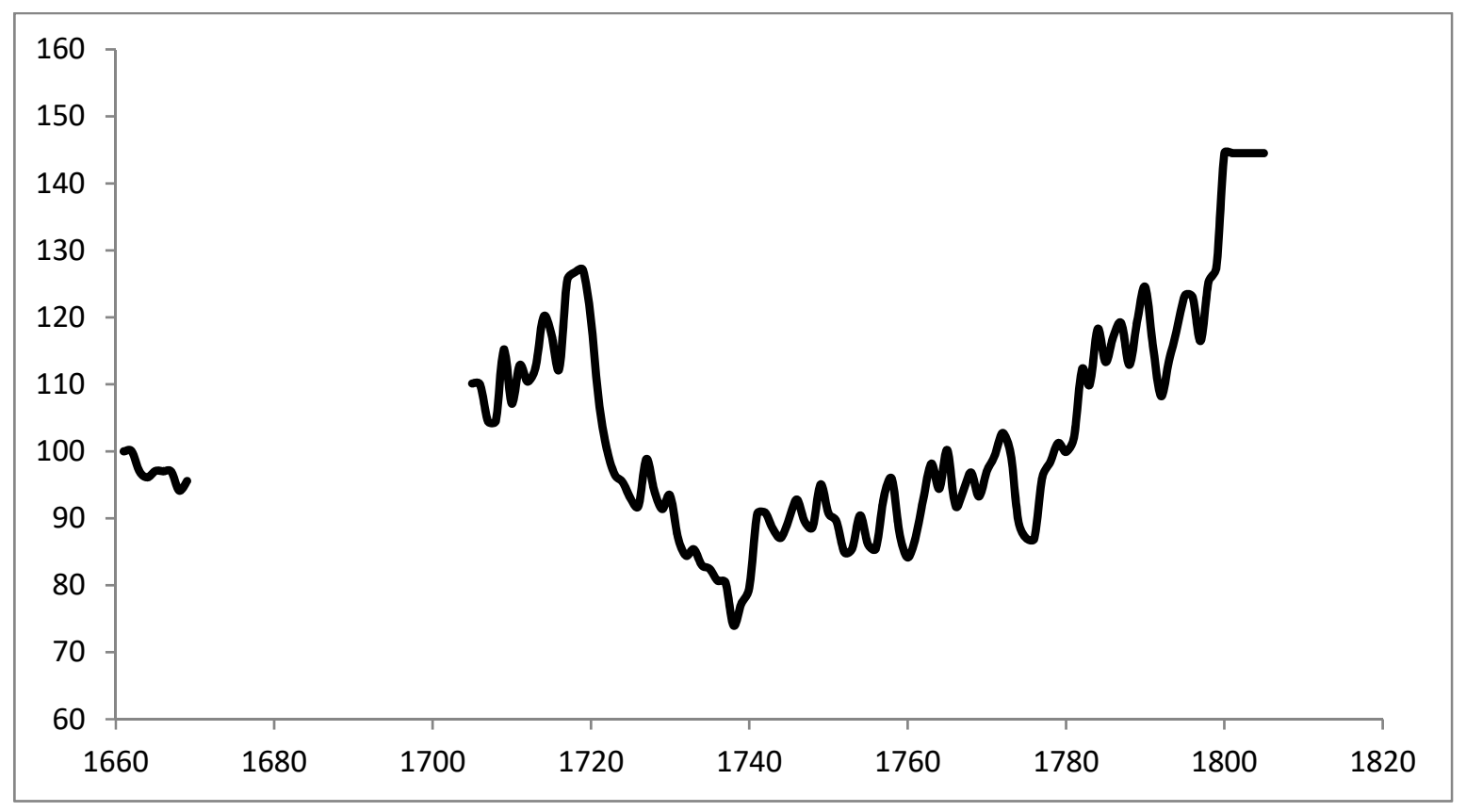

Figure 5. Consumer price index for Denmark, 1660-1805

Note: The consumer price index is calculated by applying OLS regression method and estimating equation 2 (see text). Source: author's calculations

As in the case of nominal wages, the span from 1660 to 1670 is also one with a relatively constant CPI. Next, the period of the Great Northern War is correlated with a period of inflation in prices. This was followed by a long deflation period after the peace that lasted until 1740 . At the end of this period, the agricultural sector, on which the country relied, was facing a crisis because of the low prices. The rest of the century was characterised by a constant increase in the CPI.

Plotting the real wage for Denmark in figure 6, we can observe the same movements, correlated with the involvement in the Great Northern War at the beginning of the century as in the nominal wages. But because of the evolution of the prices, these movements are less significant. On the other hand, the deflation makes the spikes in wages during the agricultural crisis very visible. The drop in real wages is also more visible after 1733, as wages were lower, and the prices started to increase. It is interesting to note that the modest gains in nominal wages through the second part of the century were eroded by increasing prices, leading to an approximately constant real wage. 


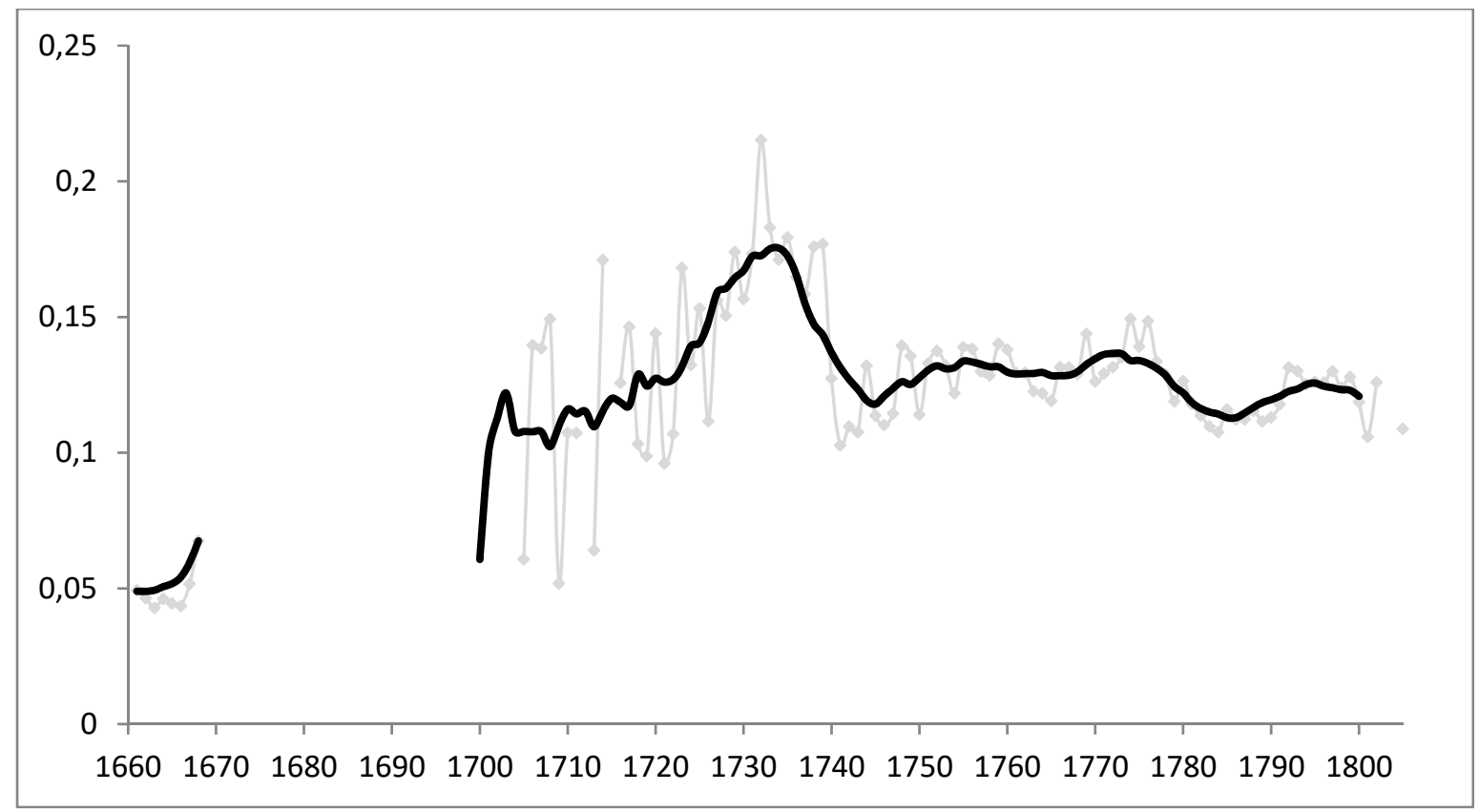

Figure 6. Real wages for men, women and children, 1660-1805

Note: The real wage series resulted from dividing the nominal wage by the consumer price index (see text). The black line represents the 10 year moving average. Wages are expressed in skilling/day. Source: author's calculations

Comparing the wages of children and unskilled adults in figure 7, we can observe that the difference between the salaries of adults and children grew over the course of the century. On average, an unskilled adult received a wage that was three times as high as that of a child. The difference was smallest during the agricultural crisis of the 1730s when cheap unskilled labour was in high demand, with an unskilled adult getting only $21 \%$ more than a child, but after the situation stabilised, the wages of children rose and tell more slowly than those of adults. 


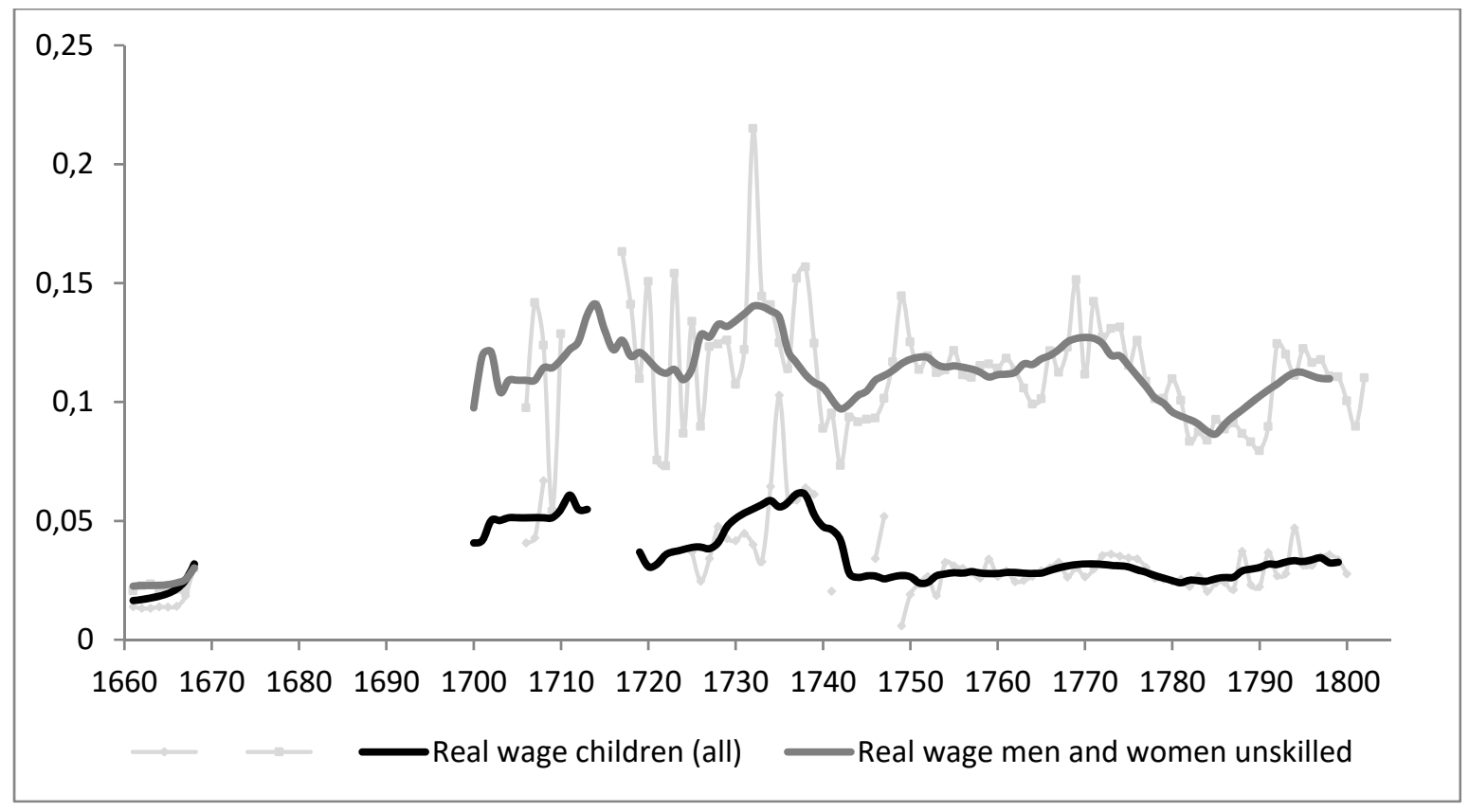

Figure 7. Real wages for children and unskilled adults, 1660-1805

Note: The real wage series resulted from dividing the nominal wage by the consumer price index (see text). The nominal wage series resulted from applying OLS regression method and estimating equation 1 (see text). The bold lines represent the 10-year moving averages. The real wages for the adults are for the lowest category in the HISCLASS, namely the unskilled group. Wages are expressed in skilling/day. Source: author's calculations

The data allows us to zoom into the several skill categories, and track the evolution of the real wage series for each HISCLASS categories. Out of the four skill categories, the high skilled class was the most problematic due to the lower number of observations towards the beginning of the series. For the period 1661-1668, the value of the wage for high skilled workers was around 160 sk. per day, much larger than the maximum of 9 sk. per day for the other categories. Therefore, the high skilled wages for this period were discarded as outliers. Additionally, in the case of teachers, many of them received very low salaries from the manors, comparable to those of labourers, while some of them did receive wages comparable to those of other high-skilled occupations. Such large variations can have an important impact on the series, and thus all observations of teachers were excluded from the calculation. The reason for such large variations is that the contributions from the manor most likely accounted for only part of a teacher's total salary. The real wages by HISCLASS are shown in figure 8. 


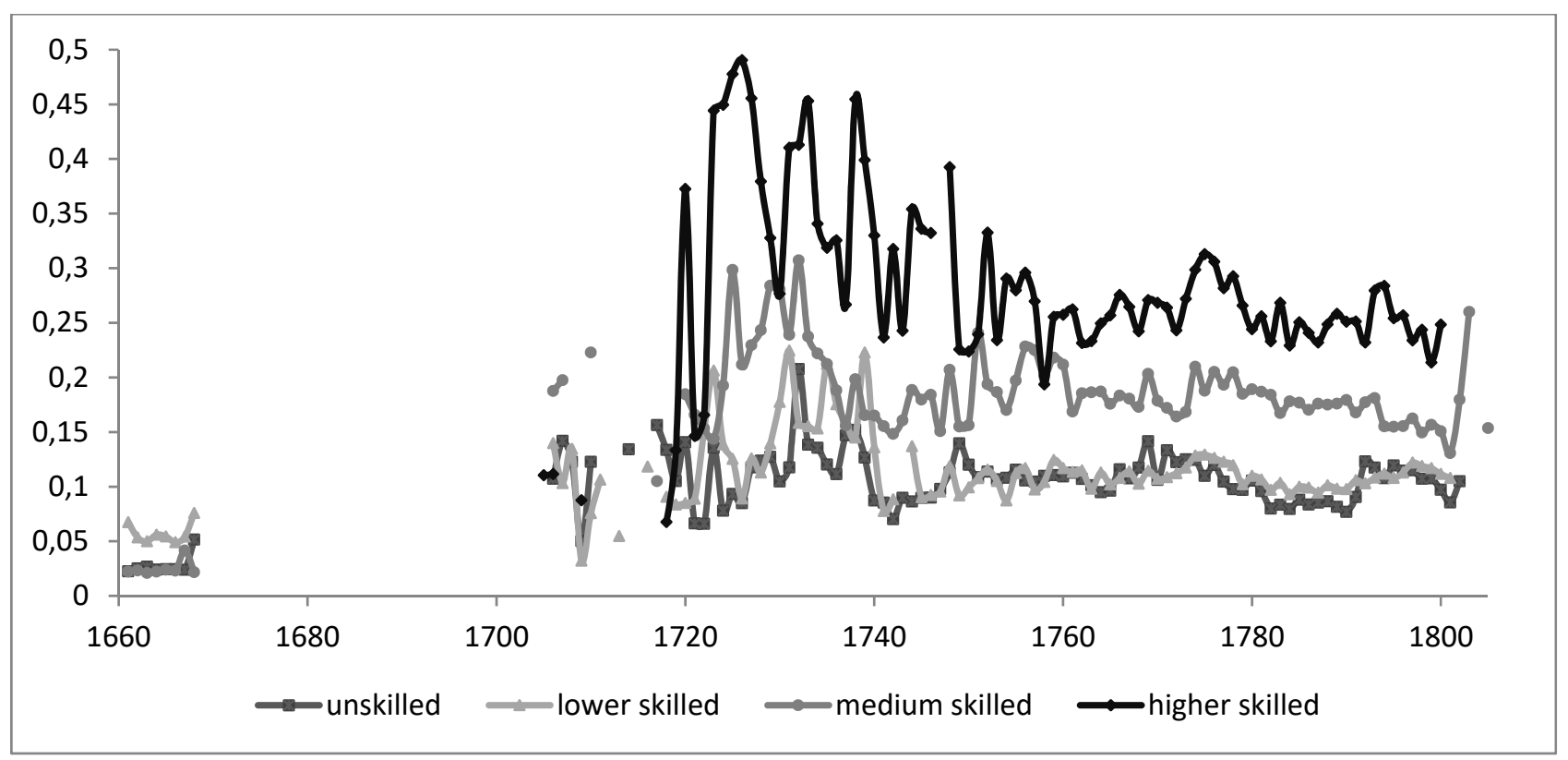

Figure 8. Real wages by HISCLASS for unskilled, low skilled, medium skilled and higher skilled workers, $1660-1805$

Note: The real wage series resulted from dividing the nominal wage by the consumer price index (see text). The various colours represent the HISLASS division, and the wages are expressed in skilling/day. Source: author's calculations

For highlighting the differences in earnings between unskilled labourers and those classified as medium skilled in the HISCLASS classification, I calculated the skill premium. A value of one indicates that, for example, a labourer earned the same amount as a craftsman, while a value of two shows that the craftsman earned twice the labourer's income. The results are presented in figure 9. The skill premium shows large variations and an average value around 1.8, this result is in contrast with the more developed countries which had a more constant skill premium with a value around 1.5 (Van Zanden 2009). As a general observation, the skill premium seems to indicate that Denmark did not belong to the most advanced countries in the Little Divergence debate, but that it had a better position than the Eastern European countries. An interpretation would be that a higher skill premium indicates a less favourable institutional environment that makes taking an education more difficult and thus slows down human capital accumulation. 


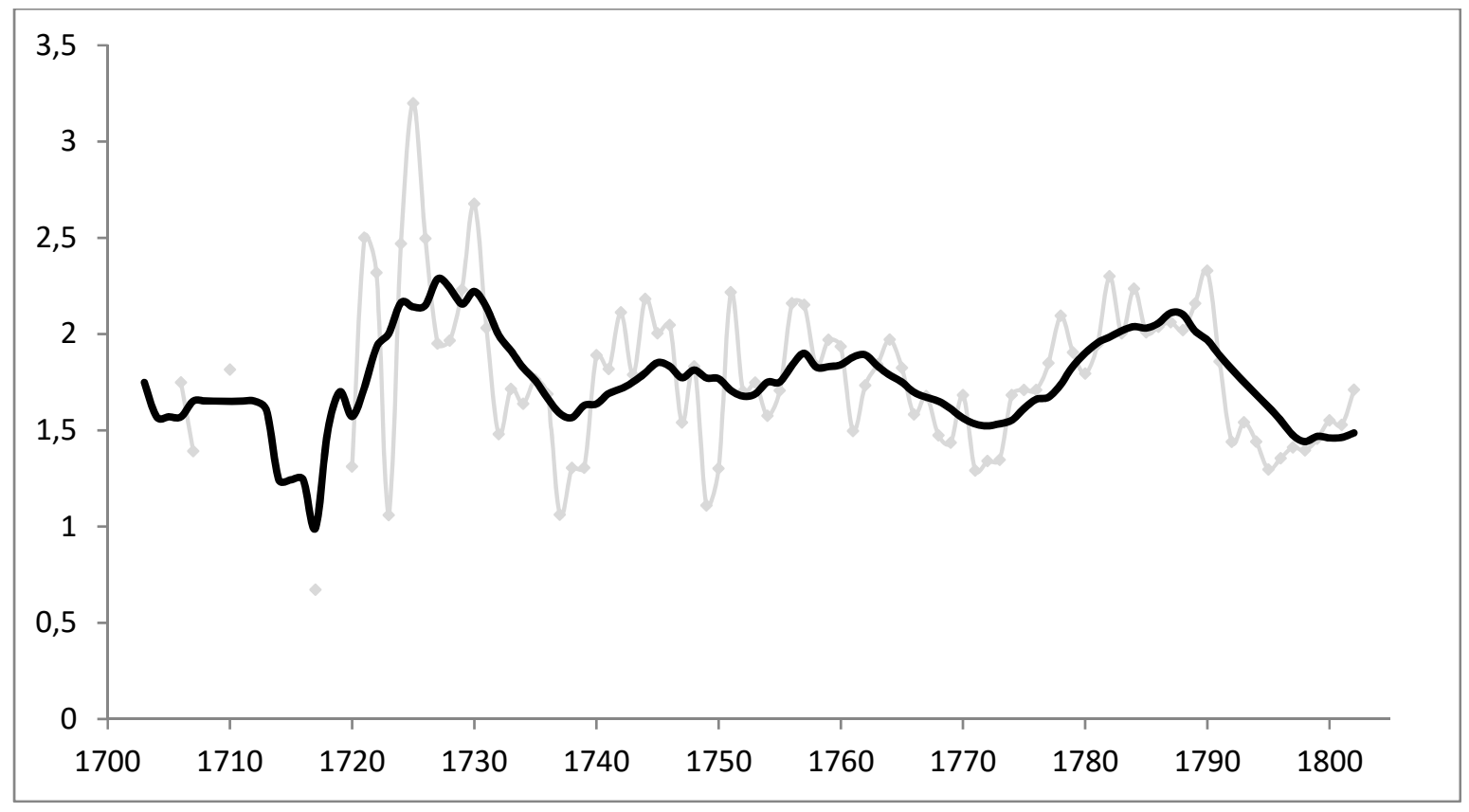

Figure 9. Skill premium (medium-skilled/unskilled workers), 1700-1805

Note: the skill premium is calculated as the ratio of nominal wages for the medium skilled workers to the wages for the unskilled workers, according to the HISCO and the HISCLASS division. The observations for the period 1661-1669 were very few and thus, were excluded from the calculation. Source: author's calculations

Additionally, large variations in skill premium can also slow down human capital formation by making education a risky investment. Like Clark (2005) and Khaustova and Sharp (2015) we do not see a significant increase in the skill premium in the second part of the eighteenth century, which could be considered part of the run-up to the industrialisation of Denmark, which took place in the second half of the nineteenth century. This would support theories that link increased incentives for human capital accumulation with the run-up to modern economic growth.

The detailed price data allow the construction of regional consumer price indices for most of the eighteenth century, and the results are presented in figure 10. The price levels in the three regions have a strong correlation in the second part of the century, but the prices in Jutland are consistently lower than those in Zealand, and Funen lies in the middle. One interesting fact is that during the Great Northern war, the region of Zealand saw strong inflation, with the consumer price index peaking at 158 in 1719, while the consumer price index for Jutland stays relatively flat with values under 90 . After the end of the war in 1720, Zealand saw strong deflation and the prices from the two regions converged. This would suggest that the war effort had a strong impact on prices in Zealand, but did not impact prices in Jutland much. 


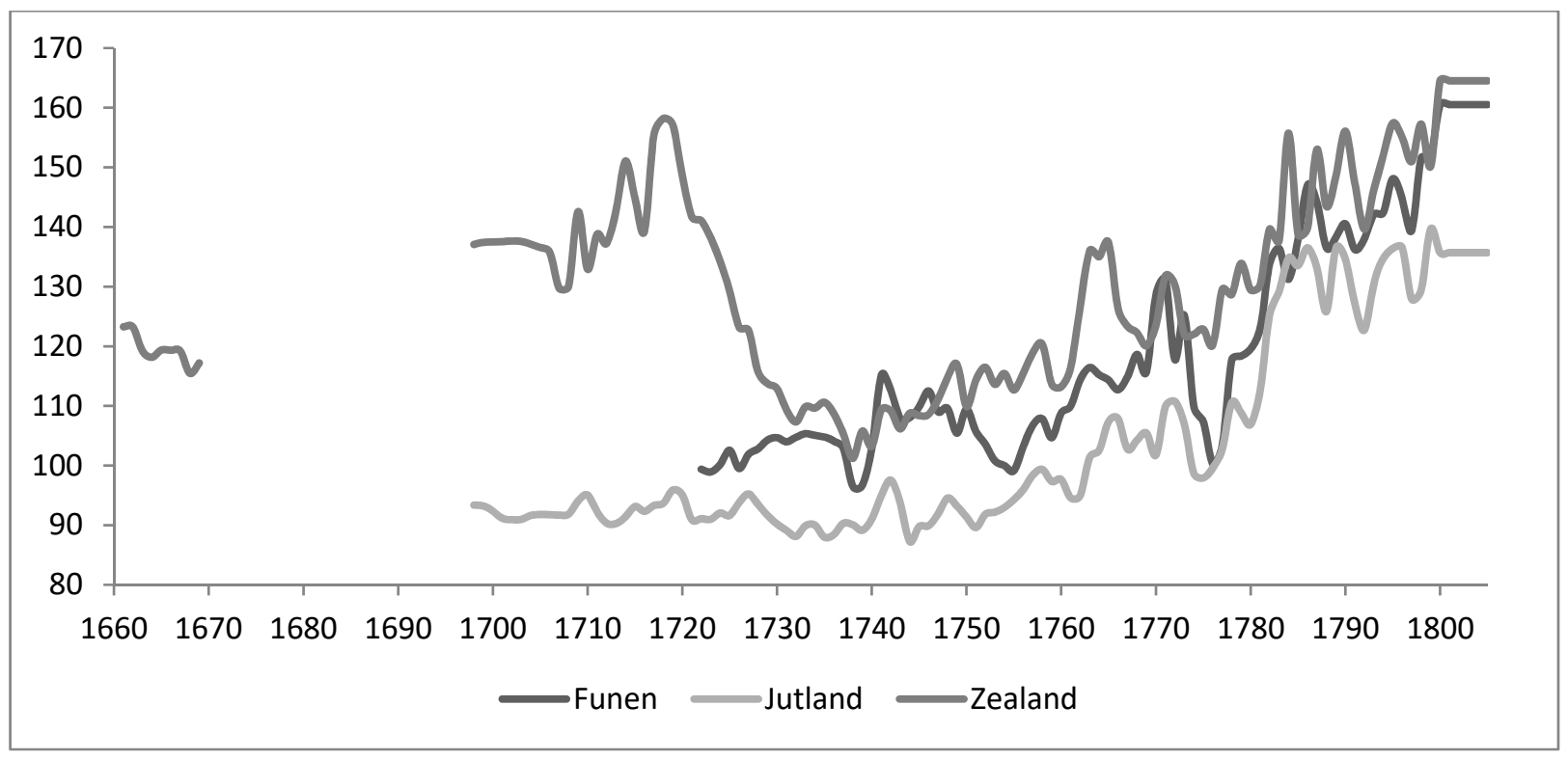

Figure 10. Regional consumer price index for the Kingdom of Denmark, 1660-1805

Note: The regional consumer price index is calculated for the three regions of the Kingdom of Denmark, namely Zealand, Funen and Jutland, by applying OLS regression method and estimating equation two (see text). Source: author's calculations

Observing the real wage from a regional perspective in figure 11, we see the same trend of convergence, with real wages in the three regions reaching similar levels towards the end of the century. On the other hand, closer to the beginning of the century there were some periods of divergence in regional income levels. One such period lasts from the 1740 s to the end of the 1750s, for the region of Funen, where real wages were consistently lower than in the rest of the country. The period of decreasing wages correlates well with the outbreak of the cattle plague in the 1740s. At the time Funen had a more developed dairy sector, so it is likely that such an outbreak had a large impact on the income of workers from the region. Real wages only reached similar levels to the rest of Denmark a decade after the outbreak of cattle plague had ended. 


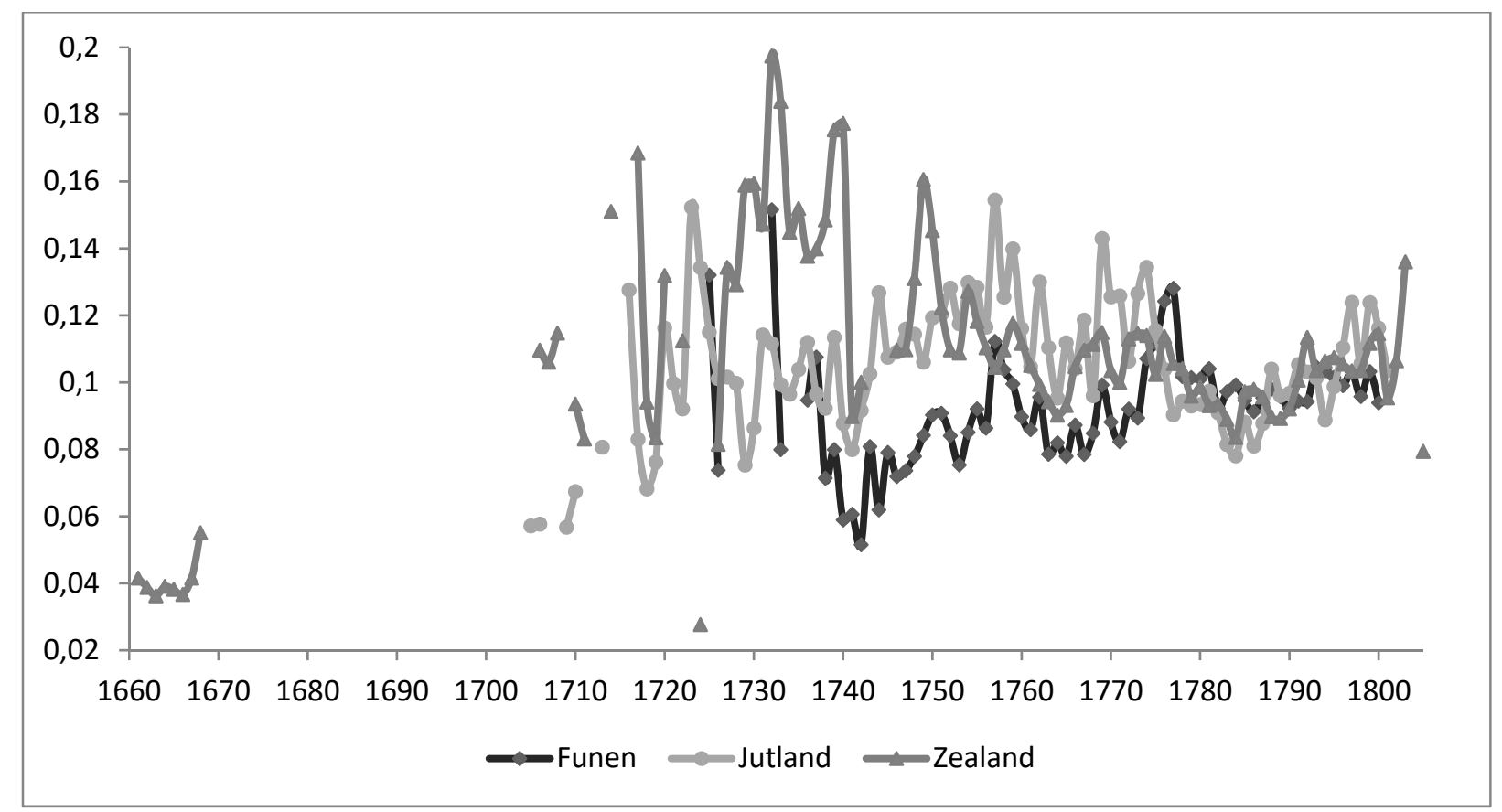

Figure 11 Real wages by region, 1660-1805

Note: The real wage series resulted from dividing the nominal wage by region to the consumer price index (see text). Wages are expressed in skilling/day and are for men, women and children. Source: author's calculations

It can also be noted that in the first part of the century, during the 1730s, the real wages were higher in Zealand than in the other regions. This development was driven by the strong decreases in the consumer price index but also because of an increase in nominal wages. One explanation is that the proximity to Copenhagen tempted more unskilled labourers to abandon the farms and move to the city, as Copenhagen was the centre of trade in the kingdom and of a small industry sector catering for the army. From this perspective, the introduction of serfdom in 1733 can be seen as the driving factor for the decrease of the region's wages in the following period. The graph also suggests that Jutland did not see salaries rise strongly during the 1730 s and nor did the salaries decline so significantly after serfdom. This might be because Jutland was less densely populated than the other regions, offering few other alternative employment opportunities besides farming, meaning that unskilled labourers were forced to take lower paying jobs in agriculture even without serfdom. The regional real wage series is used to calculate the coefficient of variation, and results are presented in figure $2 \mathrm{~A}$ in the appendix. 
Exploring the gender gap in figure 12, we can get some insight into the difference between men's and women's wages.

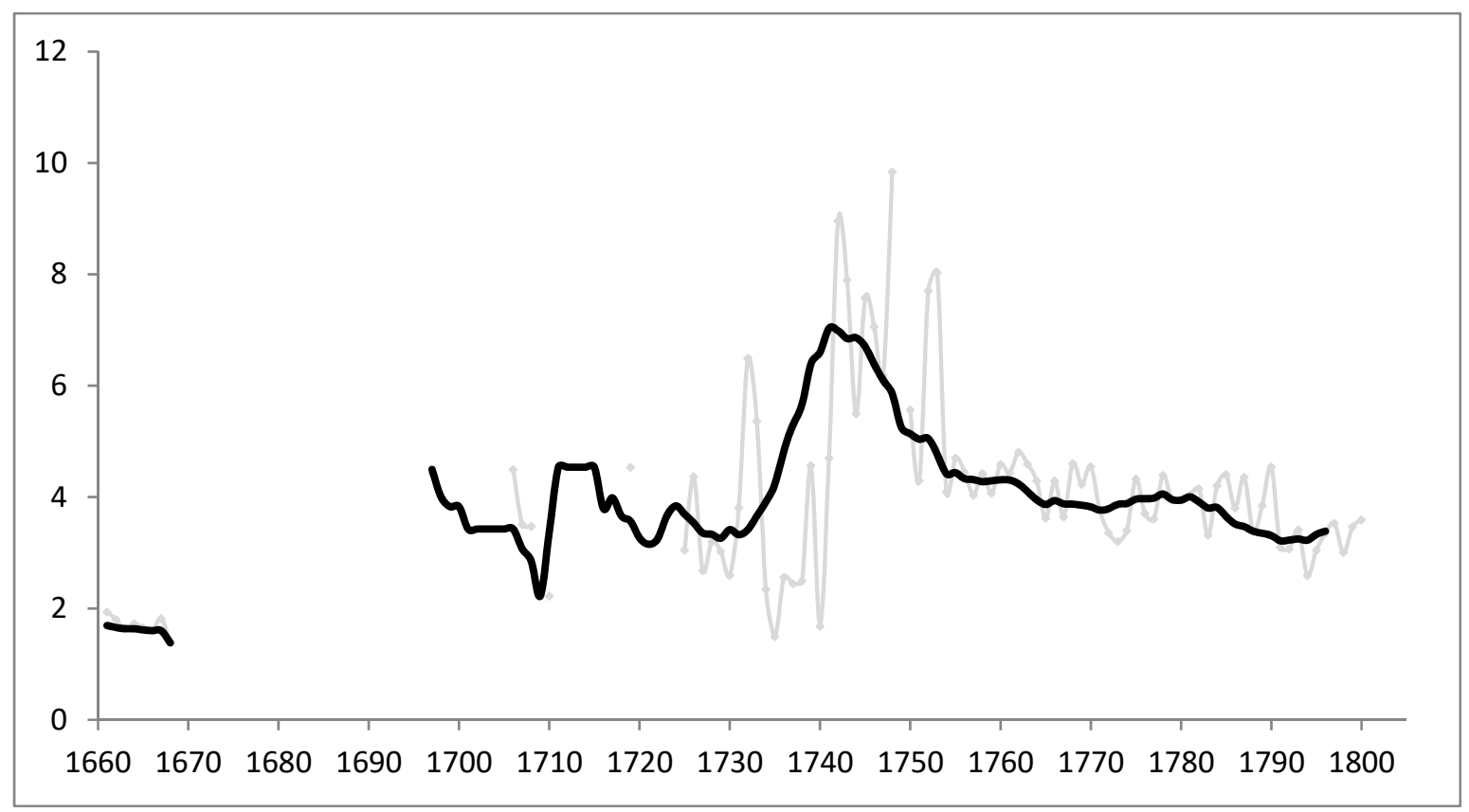

Figure 12. Gender gap, 1660-1805

Note: The gender gap is calculated as the ratio of male wages to female wages. Source author's calculations

From the big picture, it can be observed that the salaries of women were lower than those of men, with the difference actually getting larger after the introduction of serfdom and smaller towards the end of the century. This is surprising, since women were not directly affected by serfdom. ${ }^{12}$ The rich data available allow us to look at the difference between the salaries of women and men for a series of occupations, such as cook and day labourer (figure 13).

\footnotetext{
${ }^{12}$ It is still debated whether or not women were affected by serfdom.
} 

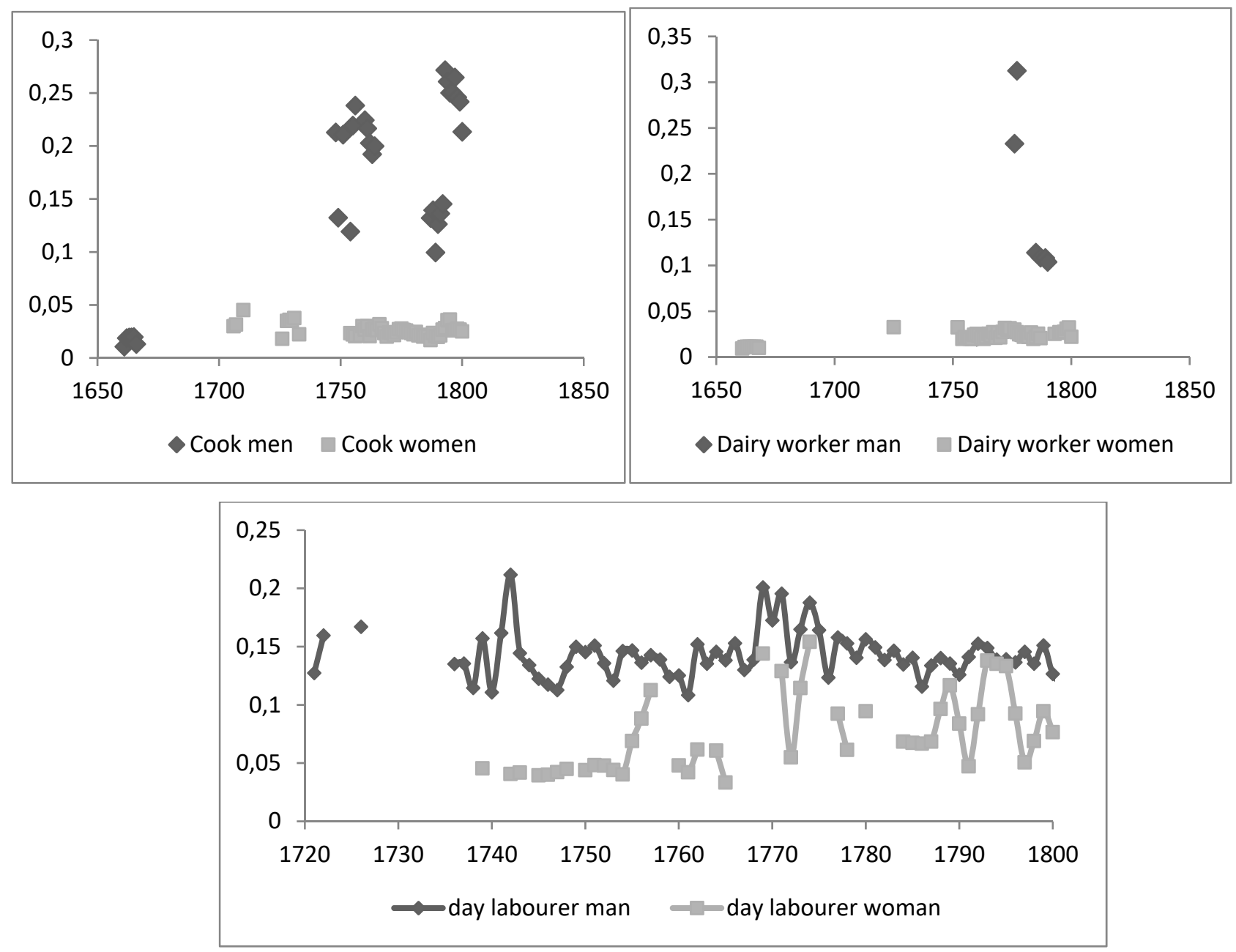

Figure 13. Gender gap for occupations: cook, dairy and day labourer, 1660-1805

Note: the gender gap is calculated as the ratio of men wages to women wages for occupations: cook, dairy worker, and day labourer. The nominal wage series resulted from applying the OLS regression method and estimating equation 1 (see text). Source: author's calculations

In the case of cooks, men earned over two times more than women, one explanation for this being that men had supervisory roles such as chefs. However, the same difference is seen in the case of day labourers, where supervisory roles were done by craftsmen. Here, men earned 2,5 times more than women at the start of the period, but towards the end they only earned 0,75 times more, suggesting that the incentive for women to join the labour force was increasing. It is interesting to note that the data enable us to establish the marital status of most of the women for whom wage observations are available. Specifically, I use the fact that in the denominations of occupations, it read in Danish:"pige"=girl and "kone"=wife. Often, the comments also specified whose wife or daughter this person was. I find that $65 \%$ of the observations are for unmarried women, while only $11 \%$ were classified as married. The rest could not be classified. One interpretation could be that this distribution, with fewer married women working on the manor, suggests that women had an 
incentive to delay marriage in order to be able to work and earn more money before starting up a household, which is one of the features of the European marriage pattern (Hajnal 1965). This classification enables a comparison between the wages of married and unmarried women. Figure 14 presents a comparison between the wages of married and unmarried washerwoman and day labourers.
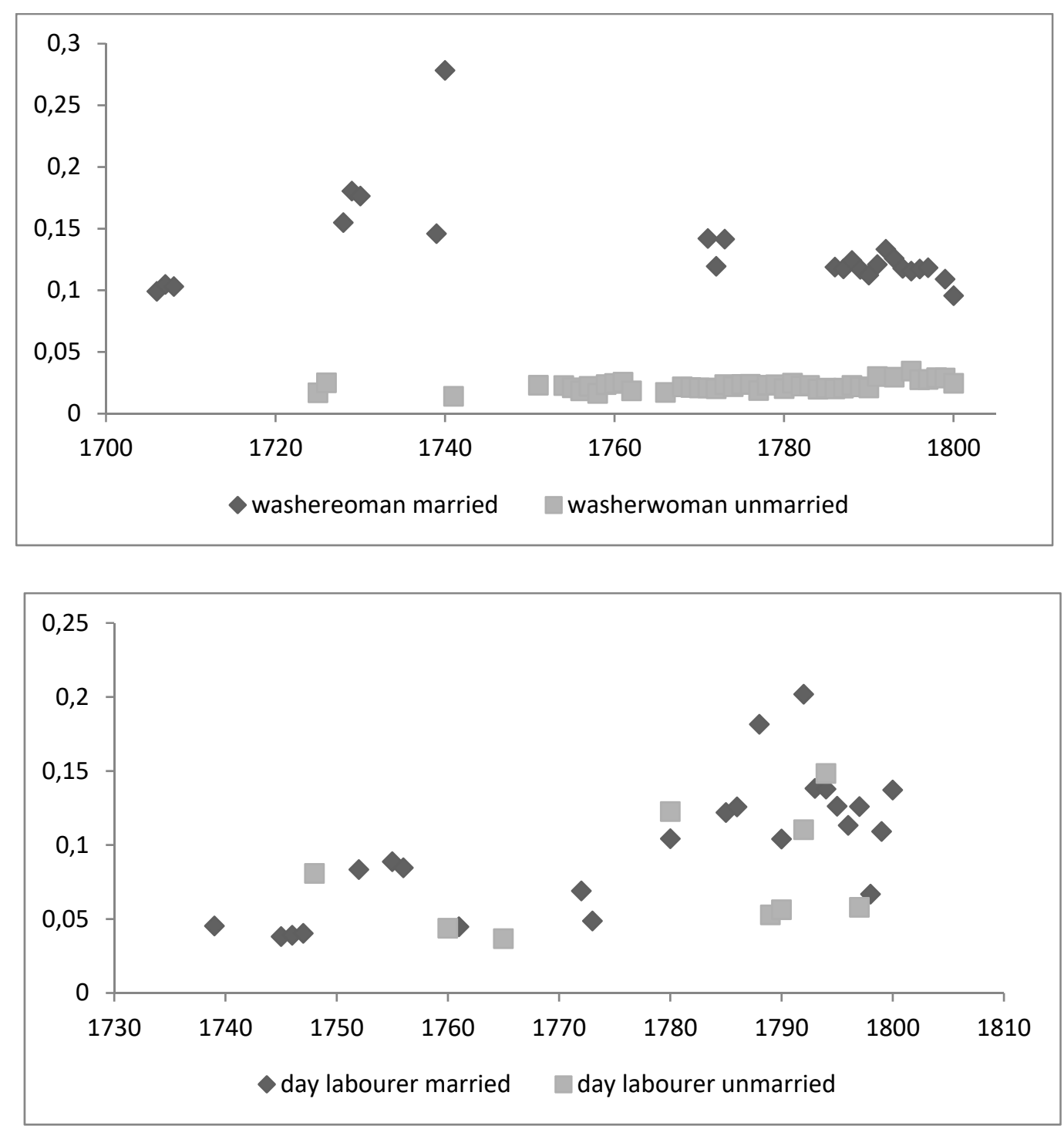

Figure 14. Wages of married and unmarried women for Washerwoman (the panel above) and day labourer (the panel below), 1700-1805

Note: The real wage series resulted from dividing the nominal wage by the consumer price index (see text). Wages are expressed in skilling/day. Source: author's calculations 
In the case of day labourers, there is no difference in wages. However, for washerwomen it is clear that married women earned more. This difference can be explained by the fact that married women tend to be older and thus can be more skilled in their occupation. While in the case of day labourers skills are not an important factor, for the washerwomen they can be the reason for the increased wages. Therefore, this suggests that, for occupations which require some degree of skills, women had an incentive to stay longer on the labour market. An alternative explanation as to why married women earned more is given by Humphries and Weisdorf (2015), who suggest that married women were able to get better jobs through their husband's connections. But in this case, the fact that this pattern is not present for day labourers seems to contradict the idea. Furthermore, the fact that the data, instead of naming the person, quite often mention whose wife or daughter this person was indicates that fathers probably had a similar role to husbands in finding a job for their unmarried daughters.

Having observations on both casual workers and long term workers enables a comparison between the wages of the two categories. $27,2 \%$ of the observations belonged to longer term workers. These tended to be medium- and higher- skilled people working on the manor, while the others were unskilled and lowerskilled, employed mainly in agriculture and construction. For some occupations, such as bricklayers and carpenters, the records show that both forms of employment were common and that casual workers doing the same job tended to earn more than the others, but this does not give the whole picture.

One difference between the two categories is that longer term workers also received other benefits besides their salary. This was true for $7.36 \%$ of long term workers. For example, some servants received allowances for buying sugar and tea, gamekeepers received extra money for buying boots and weapons, administrators received money for buying writing materials and various other manor officials also received money for buying goods important to their work, such as clothes and candles, or for keeping their own horses.

Another difference between the two categories of workers is how often they received payments in kind. The data show that nearly $20 \%$ of long term workers received some form of payment in kind, while only $1 \%$ of the casual workers received this kind of payment. In most cases, the employees were given grains, especially rye and barley, but also oats and flour, while only one employee, who received part of a cow, breaks this pattern. The Danish price history has noted down the value of these goods and our calculations show that, on average, the payment in kind was worth $47.7 \%$ of the total value of the salary. But this amount varies significantly, with extreme examples, such as a stable worker who got $99 \%$ of his pay in rye and barley and a doorkeeper who got $83 \%$ of his pay in kind. At the other end of the spectrum lie the well payed workers, such as a farm administrator for whom the payment in kind amounted to only $2 \%$.

Figure 15 presents a comparison in terms of the nominal day wages earned by casual workers (workers paid by the day) and full time workers (workers receiving payment on an annual basis). The salaries used include the value of the benefits and payments in kind. Comparing the nominal wages of temporary employees with those of full time employees it can noted that, after controlling for factors such as occupation, region etc., the salary for a full time employee was lower than that of a part time employee. One possible explanation for this difference is that long term employees received food and board from the manor. In order 
to account for this, we follow the methodology by Humphries and Weisdorf $(2016)^{13}$ and compute a third series in which we add the value of a subsistence basket of goods to the nominal salary of the full time workers. The basket (based on Allen 2009) covers the value of goods necessary to support an average family consisting of two adults and two children at a subsistence level. After adding the basket, the new series has values which are close to those of casual workers. Thus, a good explanation for the difference in the wages of full time and part time workers is that the gap equals the value of food and lodging provided by the estate to its permanent employees. This would also suggest that workers did not face a trade-off between income level and job security.

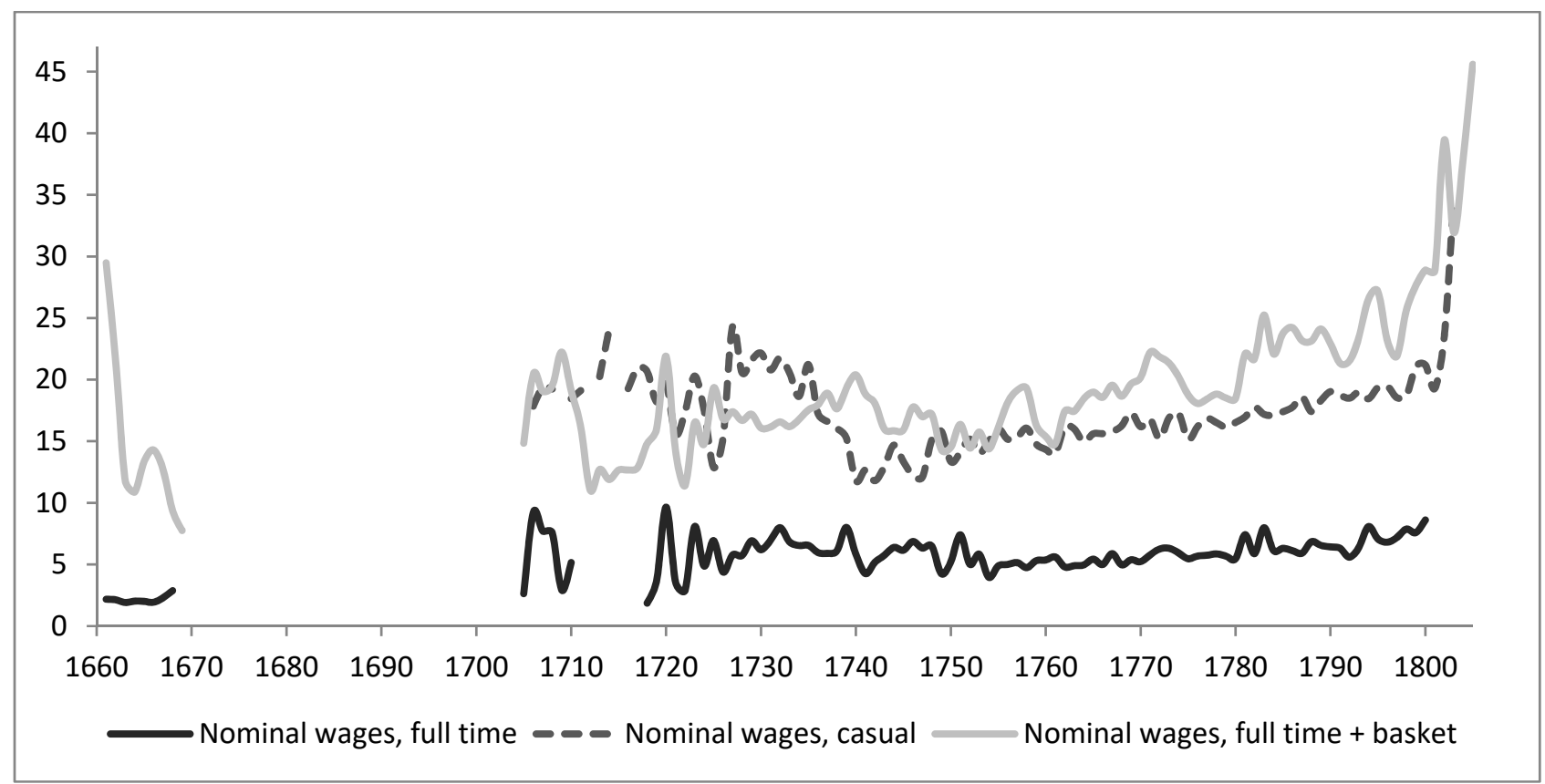

Figure 15. Nominal wages of workers paid by the day and workers receiving payment on an annual basis $1660-1805$

Note: the nominal wage series resulted from applying OLS regression method and estimating equation one (see text). The wages are expressed in skilling/day. Source: author's calculations

Another fact which should be noted is that the swings in the wages of full time employees are lower than those in the salaries of temporary workers. This is especially visible during the agricultural crisis, when the salaries of temporary workers increased and then fell after the introduction of serfdom while those of people in long term contracts did not change as rapidly. One explanation for this is that the wages of day labourers are negotiated very often, sometimes on a weekly basis, while those of full time employees are

${ }^{13}$ In Humphries and Weisdorf (2016), the authors analyze historical long run annual income series for England in order to circumvent the lack of knowledge about the length of the working year in the past. The trends in the real wages for the unskilled workers differed more than in the studies which compute annual wages based on the day wages, thus assuming 250 working days per year. 
changed only once a year, at most. Another explanation could be that the people most affected by the introduction of serfdom were the day labourers, who made up the largest share of temporary workers. Full time employees were mostly the manor officials, and they were not affected by serfdom.

\section{Rural/urban wages}

The welfare ratios obtained for rural Denmark in this study are plotted together with wages from Khaustova and Sharp (2015) and displayed in figure 16.

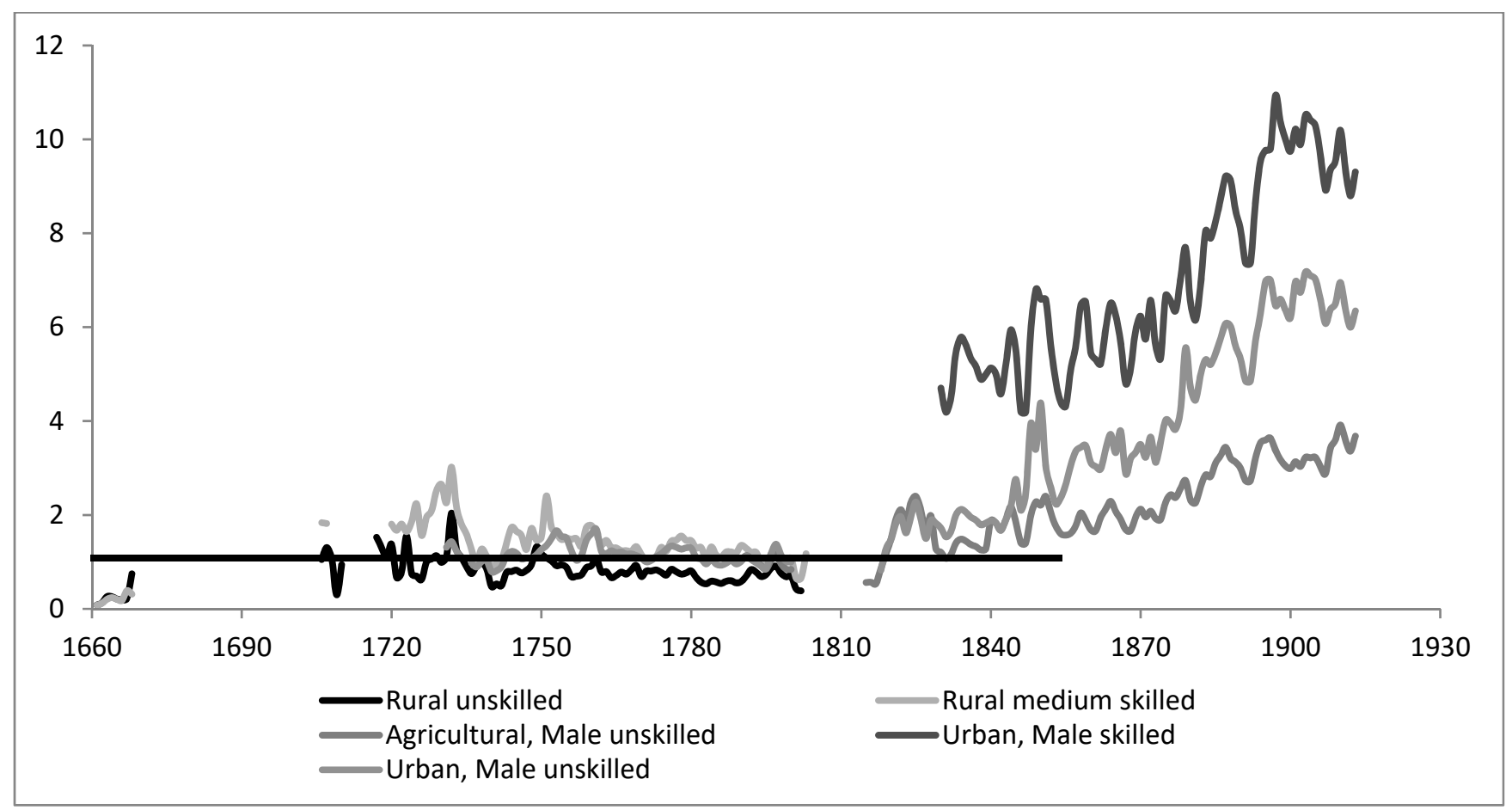

Figure 16. Welfare ratios for rural workers and urban workers (Copenhagen) 1660-1930

Note: "Rural unskilled" and "Rural medium skilled" refers to the data presented in this study whereas "Agricultural. Male unskilled", "Urban, Male unskilled", and "Urban, Male skilled" refers to the data in Khaustova and Sharp (2015). The welfare ratios are calculated as in section 5 (the welfare ratio is the average annual earnings divided by the cost of a poverty line consumption bundle for a family. A welfare ratio greater than one indicates an income above the poverty line, while a ratio less than one means the family is in poverty). The flat bold line represents the poverty line

Real wages were constant during the 18th century. This begins to change from the 19th century. This picture is similar to those from other parts of the world showing the start of modern economic growth (Allen 2009).

Comparing the welfare ratios of rural Denmark with those of labourers in Copenhagen, we observe that there was quite a large difference in the standard of living between the urban and rural inhabitants during the latter part of the century. What is interesting to note is that the welfare ratio of skilled craftsmen in rural areas is also low, just above those of labourers in Copenhagen. One explanation for this is that Copenhagen was the only part of the country which had some meaningful industry, and it was also the port through which must of the income from Denmark's large trading fleet was arriving into the country. The data from the 19th century show that the gap between Copenhagen and the rest of the country continues to 
increase as Denmark starts to evolve towards a modern economy. The gap in the graph is due to the collapse of the Danish currency during the Napoleonic wars, culminating with the state bankruptcy of 1813 . Observations on wages from this period, are meaningless. Later in the 19th century, in the 1840s we can observe a first "take-off" of the wages followed by stagnation and another "take off" in the 1870s.

Turning the attention towards the international comparison, figure 17 presents a more long term comparison between the welfare ratio of rural unskilled and low skilled workers in Denmark and the welfare ratio of the same workers in England, France, Italy and Poland. The welfare ratio was calculated following Allen (2009) using the subsistence basket described in section five. Prices for the subsistence basket after 1720 and wages after 1810 are taken from Khaustova and Sharp (2015), while wages and prices before 1700 are taken from Scharling (1869), Falbe-Hansen (1869) and the Danish Price History Project. The welfare ratios for France and Poland are calculated in Ridolfi (2017) and Malinowski (2016), while the wage data for England and Italy is taken from Clark (2005) and Malanima (2004) with the associated welfare ratios calculated in Malinowski (2016). A value of at least one indicates that the wages of one worker was enough to support an average family with two adults and two children.

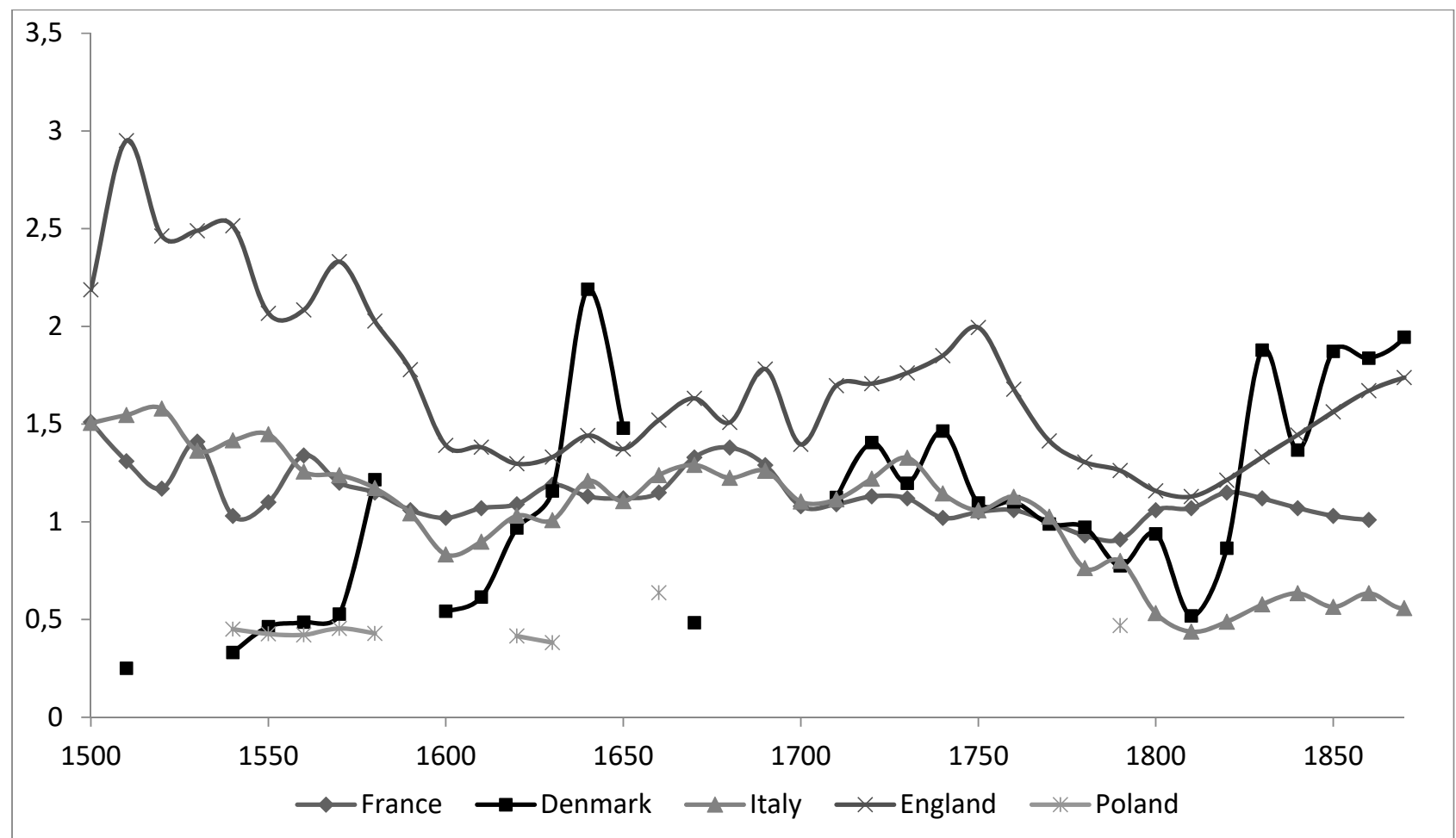

Figure 17. Welfare ratio of rural unskilled and low skilled workers in Denmark and the welfares ratio of the same type of workers in England, France, Italy and Poland, 1500-1900

Note: the series is shown for decadal averages. Source: author's calculations; the prices for the subsistence basket after 1720 and wages after 1810 are taken from Khaustova and Sharp (2015), while wages and prices before 1700 are taken from Scharling (1869), Falbe-Hansen (1869) and the Danish Price History Project; the welfare ratios of rural workers for France and Poland is taken from Ridolfi (2017) and Malinowski (2016); the rural wage data for Italy and England are taken from Malanima (2004) and Clark (2005) and the associated 
welfare ratios were calculated in Malinowski (2016)

Putting together rural wages from across Europe paints a different story than the classical story shown by urban wages. At the start of the period, around the year 1500, real wages in the English countryside were double of those in countries such as Italy or France and three times over the level required to support a family at the subsistence level. This time marked the end of the so-called 'golden age' of English peasantry, which had followed the reduction in population caused by the Black Death (Clark 2005). After 1510, wages decreased, converging towards those in continental Europe, reaching a level that was only $18 \%$ above that of France at the bottom of that trend in 1620. In the following period, wages in England and continental Europe followed a parallel trend, slowly rising until 1750 and then decreasing until 1800. This suggests that the wealth brought in by trade and the industrial revolution did not trickle down to the countryside until the start of the nineteenth century, when the welfare ratios in the countryside showed a slow increase, although it did not reach the levels seen after the great plague by 1870 . It is remarkable to note how similar the welfare ratios in Italy and France were, following a similar path up to 1790, when the French revolution happened. From this point on, French rural wages increase towards levels seen in England, while those in Italy continue to decrease to levels seen in the poorer part of Europe. Adding rural wages from Poland to this comparison shows that rural wages here were smaller than in Western Europe, having levels under the poverty line, which would allow supporting a family at a subsistence level.

Danish rural wages follow an interesting path, in the international context presented above. In the 1500 's Denmark starts as a poor country, with welfare ratios at levels comparable to those in Poland, where workers earned around half of the minimum amount they needed to support a family. From these low values, Danish agricultural wages increase after 1600, reaching numbers comparable to those in England in the 1640 's and 1650's. At this time, the kingdom controlled access to the Baltic Sea and the state grew wealthy from collecting Sound dues from passing merchant ships. After 1640's, wages in Denmark decrease to a level comparable to that in countries in continental Europe. This decrease corresponds with the start of a series of wars with Sweden which lasted from 1640's to 1720's in which Denmark lost control of the Baltic sea. In the years of peace after the Great Northern War and up to the Napoleonic Wars, welfare ratios in Denmark have levels very similar to those in Italy and France. During the Napoleonic wars, Denmark picks the French side and is defeated, facing a state bankruptcy in 1813 , which is reflected by low welfare ratios, comparable to those in the 1500's. However, after this low point, rural wages in Denmark started to rapidly increase, reaching levels similar to England. At the time, Danish agriculture was having success in exporting agricultural produce to England, first with grains and later with dairy products. One reason for the strong increase in Danish rural wages towards the end of the series was that, unlike in other countries, Danish agriculture lead the transition to modern economic growth, with innovations such as cooperative creameries making this sector competitive on the export market, which in turn generated demand for railways and industrial goods (Lampe and Sharp 2018) 


\section{Discussion and conclusions}

The large amount of data on wages enables an evaluation of the conditions on the labour market in eighteenth century Denmark and provide information on the position of Denmark in the Little Divergence debate, seen from a rural perspective. In the first part of the eighteenth century, which was when events like the Great Northern War, the farming crisis and the introduction of serfdom took place, large variations in wages can be observed. The second part of the century did not have any major political events, so only a small increase in nominal wages and stagnation of real wages could be observed. The most notable event during this period, from the point of view of wages and prices, was the agricultural crisis of the 1730s, when wages reached high levels at the same time as a period of low grain prices. This was the moment when landowners managed to introduce serfdom, in order to secure a cheap labour force for their farms. This form of labour coercion was only abolished towards the end of the century. By looking at the real wage from a regional perspective, it is apparent that incomes were stagnating during this period in all three regions. We can observe a trend of convergence in income, with real wages showing large regional and temporal variations following the events at the start of the century which reduce in amplitude towards the end of the period.

Analysing labour market conditions further, we observe that the value of the skill premium calculated using the wages of unskilled labourers and craftsmen was more unstable and higher than that of leading countries in Europe, with skilled workers earning an average of $80 \%$ more their helpers. This can often be associated with less developed institutions that have a role in human barriers to social mobility, like serfdom.

On top of that, analysing the real wages of women supports the idea that the economy was less developed, as most women present in the data set were doing unskilled labour. Calculating the wage gap for the for skilled occupations shows that salaries of men could be more than three times those of women, most likely because men only had a supervisory role in occupations, such as dairying or cooking, and women were doing most of the labour. Comparing day labourers, on the other hand, reveals a smaller wage gap, which decreases in value during the century, with men only earning on average $50 \%$ more than women at the end of the period, suggesting an increasing incentive to enter the workforce for women. The detailed data allow a comparison between the wages of married and unmarried women that reveals women in occupations requiring skills earned more when they were married, but day labourers showed no difference in wages. Because marriage status is correlated with age, the result suggests that women doing skilled occupations, who had more experience, got better wages, and thus women having skilled occupations had an incentive to stay longer on the labour market.

Looking at incomes of casual and full time workers, we can observe that the latter had incomes that were consistently lower than those of casual workers, assuming the same number of days worked. However, if we take into account that full time workers were usually offered room and board by the manor, adding the value of a subsistence basket to their yearly incomes pushes up their wages to a level remarkably similar to that for part time workers.

Finally, putting the new data together with other sources to form a longer term series of rural real 
wages, from a number of countries across Europe, paints a somewhat different picture of the little divergence than the one that is revealed when comparing urban wages. While England, around 1500, did see rural wages that were higher than those in continental Europe (represented by France and Italy), during the sixteenth century incomes drop, converging to a value that is only around $20 \%$ higher than in France and Italy. The next two centuries, rural wages in both England and continental Europe stagnate, only to diverge again in the $19^{\text {th }}$ century. Poland is also present in the comparison, and rural wages there stagnate at a level that is lower than that in western Europe for the available period. In this context, Denmark follows an interesting path, starting out as poor, with wages at the same level as Poland in the sixteenth century. Wages rise in the first half of the seventeenth century and stabilise at a level similar to Spain and France in the eighteenth century. In the nineteenth century rural wages in Denmark take off, reaching levels similar to those in England, as Danish agriculture was becoming successful in exporting produce, especially to England. The more detailed analysis for the eighteenth century sheds some light on some probable causes of the unfavourable real wage development at that time in Denmark. 


\section{References}

Abildgren, K. (2010). Consumer Prices in Denmark 1502-2007. Scandinavian Economic History Review 58:1, pp. 2-24.

Abildgren, K. (2017). Trends in real wages in Denmark since the Late Middle Ages, Historical Methods: A Journal of Quantitative and Interdisciplinary History, 50:2, 67-78

Allen, R. C. (2001). The Great Divergence in European Wages and Prices from the Middle Ages to the First World War. Explorations in Economic History 38 (October): 411-47.

Andersen, D., Oxenvad, N., and Thestrup, P. (1986). Mod bedre tider. Odense 1789-1868. Odense: Odense Universitetsforlag.

Andersen, D.H. and Pedersen E.H. (2004). A History of Prices and Wages in Denmark, 1660- 1800. Vol. II: Prices and Wages in Danish Estate Accounts. Copenhagen: Schultz

Christensen, J. (1985). Landbostatistik: Håndbog i dansk landbohistorisk statistik 1830-1900. Copenhagen: Landbohistorisk Selskab.

Clark, G. (2005). The Condition of the Working Class in England, 1209-2004. Journal of Political Economy, Vol. 113, No. 6, pp. 1307-1340

Clark, G. (2007), The Long March of History: Farm Wages, Population and Economic Growth, England 1209-1869. Economic History Review 60, pp. 97-136.

Collins, William J. (1999). Labor Mobility, Market Integration, and Wage Convergence in Late nineteenth Century India, Explorations in Economic History, 36, no. 3, pp. 246-277.

Dall Schmidt, T., Jensen, P.S., Naz, A., (2018). Agricultural productivity and economic development: the contribution of clover to structural transformation in Denmark. Accepted at Journal of Economic Growth.

de Pleijt, A.M. and J.L. van Zanden (2016). Accounting for the 'Little Divergence': What Drove Economic Growth in Pre-Industrial Europe, 1300-1800?, European Review of Economic History, vol. 20, no 4.

de Pleijt, A.M. and Weisdorf, J.L. (2017). Human capital formation from occupations: the 'deskilling hypothesis' revisited. Cliometrica, vol. 11, no. 1

Edvinsson, R., and J. Soderberg. (2011). A consumer price index for Sweden, 1290-2008. Review of Income and Wealth 57:270

Falbe-Hansen, V. (1869). Prisernes og Arbejdsı ønnens Historie i Danmark

Falbe-Hansen, V. (1888). Stavnsbaands-Løsningen og Landboreformerne. Copenhagen: J.H. Schultz.

Falbe-Hansen, V. (1889). Stavnsbaands-Løsningen og Landboreformerne. Set fra Nationaløkonomiens Standpunkt. 1ste Del. - Tiden fra 1733 til 1807. Copenhagen: J.H. Schultz

Friis, A., and Glamann, K. (1958). A History of Prices and Wages in Denmark: 1660-1800. Vol 1. London: Longmans, Green and Co. 
Gary, K. (2018). Wages in comparison Scandinavia in the early modern period: Evidence from Scania. Unpublished manuscript

Goldin, C. (1994): The U-Shaped Female Labor Force Function in Economic Development and Economic History, Investment in Women's Human Capital and Economic Development, University of Chicago Press, 1995

Grytten, O. H. (2009). Purchasing power of labour: Norwegian real wages, 1726 - 2006. Scandinavian Economic History Review 57:48 - 87

Hajnal, J. (1965). European Marriage Patterns in Perspective. In D. V. Glass \& D. E. C. Eversley (Eds.), Population in History. Essays in Historical Demography. Volume I: General and Great Britain (pp. 101-143). New Brunswick (U.S.A.): Aldine Transaction.

Hansen, S.A. (1984). Økonomisk vækst i Danmark. (2 volumes). Copenhagen: Akademisk Forlag.

Henriksen, I., (2006). An Economic History of Denmark. EH.Net Encyclopedia of Economic and Business History. ed. / Robert Whaples. http://eh.net/ : EH.Net, 2006.

Humphries, J., and Weisdorf, J. (2015). The Wages of Women in England, 1260-1850. Journal of Economic History 75, pp. 405-447.

Humphries, J. , and Weisdorf , J. (2018). Unreal wages? : Real income and economic growth in England, 1260-1850, Economic Journal

Jensen, P. S., Lampe, M., Sharp P., and Skovsgaard, C. (2018a). A Land 'of Milk and Butter' :The Role of Elites for the Economic Development of Denmark. Working paper

Jensen, P.S., Radu, C., Battista, S., Sharp, P. (2018b). The introduction of serfdom and labor markets. Working paper

Johansen, H. C. (2002). Danish Population History, 1600-1939. University of Southern Denmark in History and Social Sciences. Odense: University Press of Southern Denmark.

Khaustova, E., and Sharp, P. (2015). A note on Danish living standards through historical wage series, 1731 - 1913. Journal of European Economic History 44:143

Kjærgaard, T. (1994). The Danish revolution, 1500-1800: an ecohistorical interpretation (Cambridge, 1994)

Jorberg, L. (1972). A History of Pricess in Sweden, vol. 2, Lund

Malanima, P. (2004): Labour, Productivity, Wages in Italy, 1270-1913, Towards a Global History of Prices and Wages, 19-21 Aug, 2004

Marco, H.D. van Leeuwen, Maas, I., and Miles, A. (2002). HISCO: Historical International Standard Classification of Occupations. Leuven: Leuven University Press. 441 pp. 
Malinowski, M. (2016). Little Divergence revisited: Polish weighted real wages in a European perspective, 1500 - 1800, European Review of Economic History, Volume 20, Issue 3, Pages 345 - 367,

Lampe, M., and Sharp, P. (2018). A Land of Milk and Butter: How Elites Created the Modern Danish Dairy Industry. The University of Chicago Press Chicago and London

Phelps Brown, E. H., and Hopkins, S. V. (1955). Seven Centuries of Building Wages. Economica 22, 195206.

Ridolfi, R. (2017): L'histoire immobile? Six centuries of real wages in France from Louis IX to Napoleon III : 1250-1860, Working paper

Scharling, W. 1869. Pengenes synkende Værdi belyst ved danske Aktstykker samt ledsaget af en kort Udsigt over den danske Mønthistorie. Copenhagen: Gads Forlag.

Söderberg, J. (2010). Long-term trends in real wages of Labourers. Sveriges Riksbank

Stephenson, J. (2018). 'Real' wages? Contractors, Workers, and Pay in London Building Trades, 16501800. The Economic History Review, Vol. 71, Issue 1, pp. 106-132, 2018

Thestrup, P. (1987). The standard of living in Denmark since c. 1750. In Levestandarden i Norden 17501914, ed. G. Karlsson, 25-45

Van Zanden, J. L. (1999). Wages and the Standard of Living in Europe, 1500-1800. European Review of Economic History 3, 175-197

Van Zanden, J. L. (2009). 'The skill premium and the "Great Divergence"'. European Review of Economic History 13:1, pp. 121-153.

Wenge M. (1987). Fra åretold til Toldetat. Middelalderen indtil 1660. Bind 1. Toldhistorisk selskab.

Ølgaard, A. (1976). Arbejdslønnen i byerne og i landbruget i Danmark 1875-1955. Copenhagen University Memo no. 49. 


\section{Appendix}

Figure 1A. Population density of the Kingdom of Denmark at the county level in 1787 and 1801 and the manors' location

Note: The location of the manors and estates is represented by the white dots. The areas that are darker represent a higher population density, while the lighter ones represent a lower density. The population density is calculated as the population in a county divided by the area of that county. Source: the population data at the country level comes from the census available on Statistics Denmark; author's calculations using GIS software

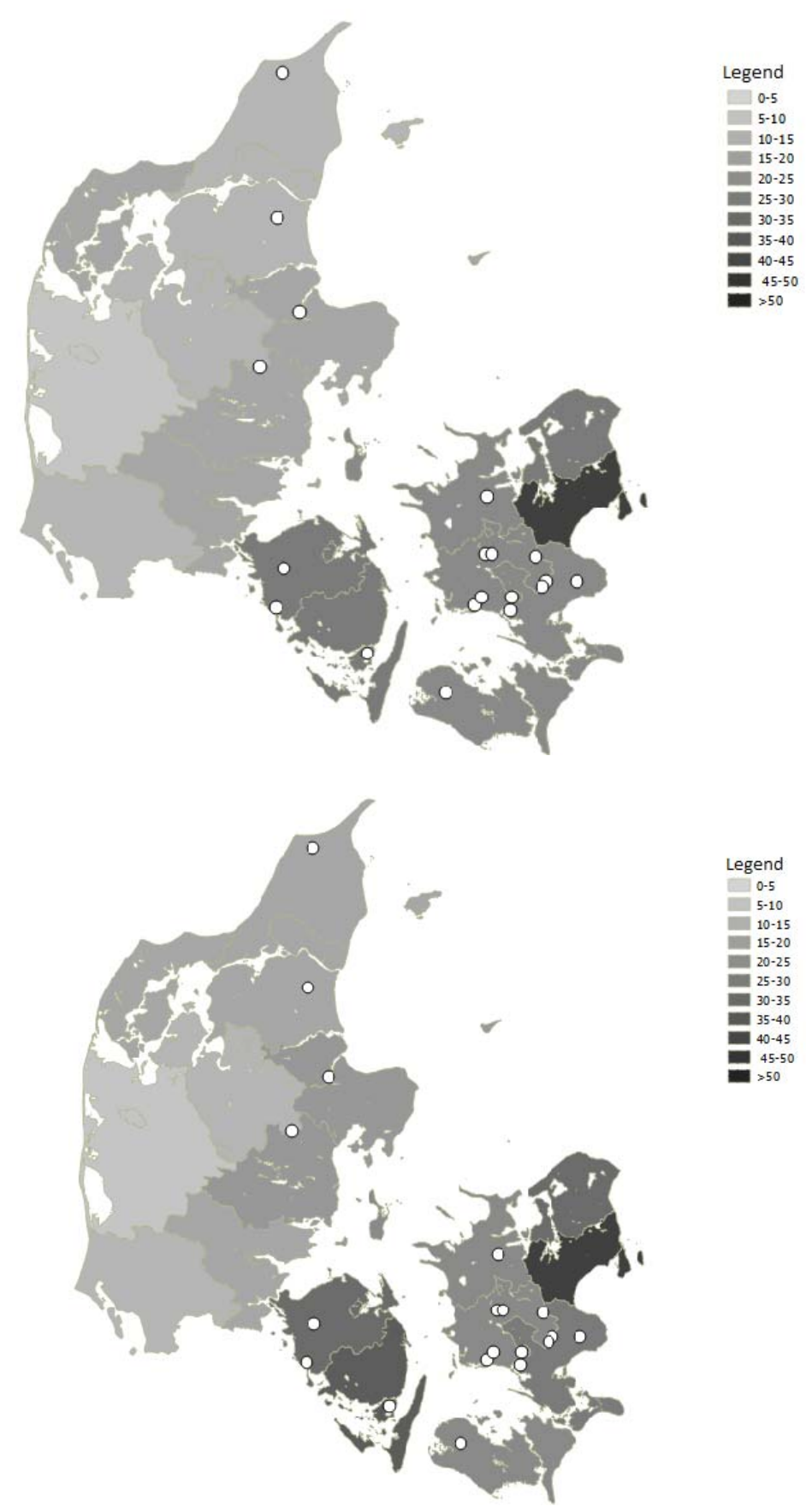


Table 1A. Occupational titles and tasks classified according to HISCO (Historical International Standard of Classification of Occupations) and HISCLASS (Historical international social class scheme). Source: author's calculations

\begin{tabular}{|c|l|}
\hline HISCLASS classification & \multicolumn{1}{|c|}{ HISCO classification } \\
\hline Unskilled & $\begin{array}{l}\text { Labourer, day labourer, demolition worker, charcoal burner, logger, } \\
\text { livestock worker, agricultural labourer, farm servant, subsistence } \\
\text { farmer, doorkeeper, watchman, chimney sweep, bell ringer }\end{array}$ \\
\hline Low-skilled & $\begin{array}{l}\text { Coachmen, wine bottler, builder, paviour, basket maker, painter, brick } \\
\text { and tile moulder (hand), stone cutter, wheelwright, net maker, } \\
\text { weaver, stone splitter, fisherman, forester, gardener, dairy, servant at } \\
\text { home, correspondence clerk, messenger, postman, barn bailiff }\end{array}$ \\
\hline Medium-skilled & $\begin{array}{l}\text { Glazier, plasterer (general), wood shipwright, joiner, carpenter, } \\
\text { stonemason, bricklayer, potter, watchmaker, smith, cooper, saddler, } \\
\text { shoemaker, seamstress, brewer, butcher, grain miller, spinner, nurse, } \\
\text { gamekeeper, forest supervisor, policeman, cook, merchant, } \\
\text { housekeeper, inspector, organist, deacon }\end{array}$ \\
\hline High-skilled & $\begin{array}{l}\text { Surgeon, doctor, tax assessor, land surveyor, farm supervisor, minister } \\
\text { of religion, head teacher, teacher, notary, government administrator }\end{array}$ \\
\hline
\end{tabular}

A few examples of highly skilled workers are head teachers, surgeons, judges, priests and surveyors. Stonemasons, carpenters, brewers and butchers are a few examples of medium-skilled jobs, while fishermen, painters, thatchers etc., are examples of lower-skilled workers. The main unskilled occupations were: labourers, day labourers, farm labourers and farm servants. In the medium-skilled category, the largest number of observations belongs to stonemasons and carpenters, while for lower-skilled jobs the most common are painters. In the unskilled category the labourers and day labourers represent the largest number of the observations. The tasks of labourers were usually digging ditches, carrying and assembling stones, working in the stable and loading timber. The farm labourers had slightly different tasks, such as, for example, working the fields, ploughing, harvesting, gathering hay etc. Women did, very rarely, have the same types of occupations as men, and these observations will be used for men/women comparisons in the later sections. Their main occupations were washerwomen, servants at home, milkmaids, seamstresses, weeding the garden etc. For children, jobs like servant at home and milkmaid are among the most frequent. 


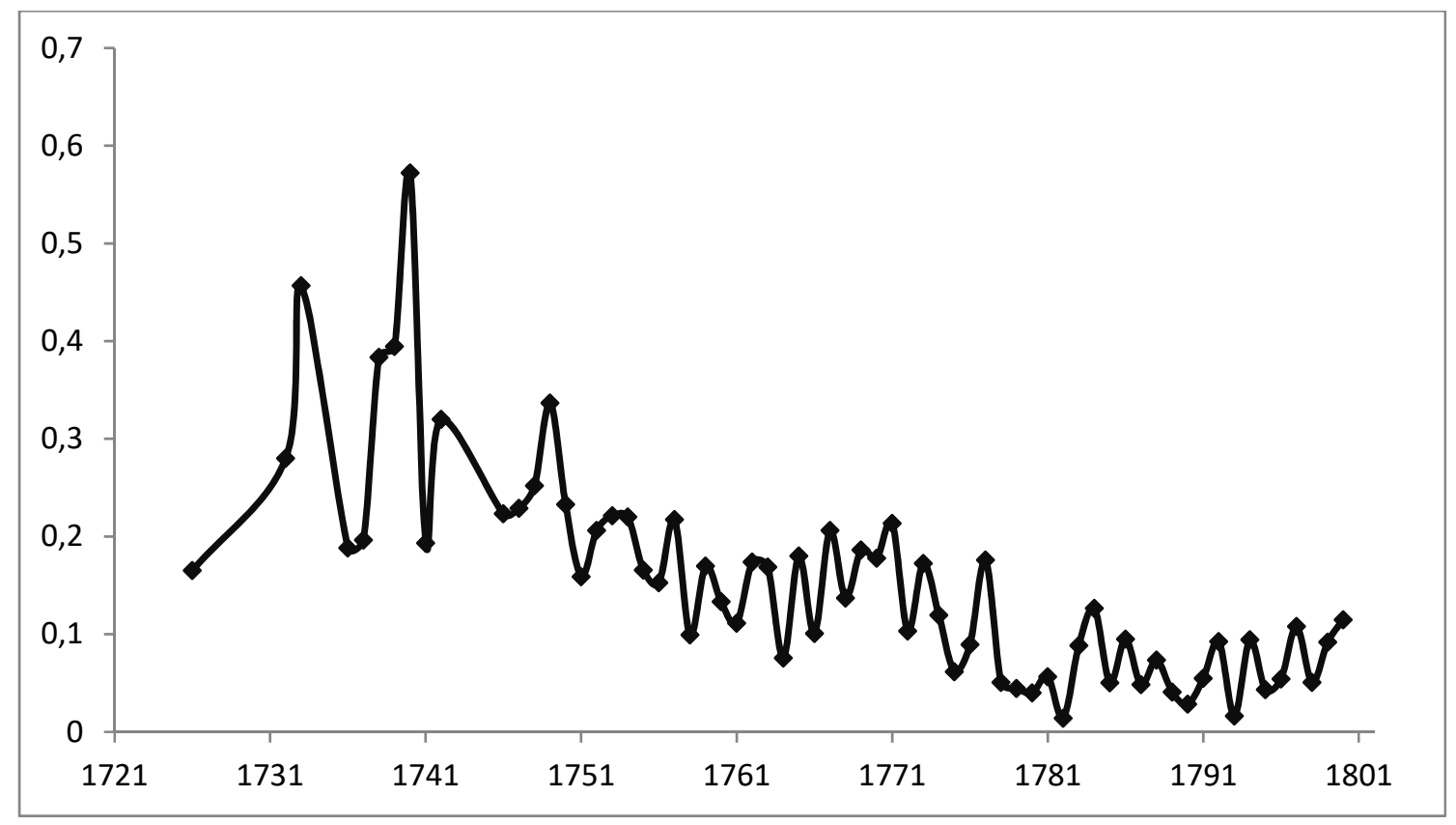

Note: Coefficient of variation is calculated as the standard deviation of the values taken from each region in a year divided by the mean. It is calculated only for the years with observations available for all three regions. Source: author's calculations

The gap between the wealthiest and the poorest regions in Denmark can be described by investigating whether there is Sigma convergence. This would mean that the difference in income per capita between the different regions should decrease over time. In order to test this assumption, the regional real wage series is used to calculate the coefficient of variation (as the standard deviation of the values taken from each region in a year divided by the mean), and the results are presented in figure below. Plotting the coefficient of variation tells the same story as the regional real wages. Denmark saw considerable Sigma convergence between 1727 and 1800, which reflects the narrowing of the gap between the richest and poorest regions. However, as seen in figure 11, the gap did not narrow by an increase of wages in the poorer regions, but rather by a decrease of wages in Zealand. Besides a spike in 1740, the coefficient of variation exhibits a downward trend after 1733, which does support the idea that the introduction of serfdom could have resulted in limited wages in the Zealand area and brought them closer to the values in the rest of the country. 